Article

\title{
Sustainable Tourism Development in the Protected Areas of Maramures, Romania: Destinations with High Authenticity
}

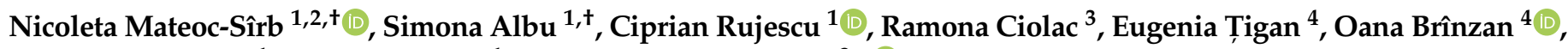 \\ Camelia Mănescu ${ }^{1}$, Teodor Mateoc ${ }^{1, *}$ and Ioana Anda Milin ${ }^{3, * \mathbb{C}}$ \\ 1 Department of Management and Rural Development, Banat's University of Agricultural Sciences and \\ Veterinary Medicine "King Michael I of Romania" from Timisoara, Calea Aradului Street No. 119, \\ 300645 Timisoara, Romania; nicoletamateocsirb@usab-tm.ro (N.M.-S.); simo_bvro@yahoo.com (S.A.); \\ rujescu@usab-tm.ro (C.R.); cameliamanescu18@gmail.com (C.M.) \\ 2 Romanian Academy, Timisoara Branch, CCDRDR, Mihai Viteazu Boulevard, No. 24, 300223 Timisoara, Romania \\ 3 Department of Economics and Financing of the Company, Banat's University of Agricultural Sciences and \\ Veterinary Medicine "King Michael I of Romania" from Timisoara, Calea Aradului, No. 119, \\ 300645 Timisoara, Romania; ramonamarianaciolac@usab-tm.ro \\ 4 Faculty of Food Engineering, Tourism and Environmental Protection, "Aurel Vlaicu" University of Arad, \\ 2-4 Elena Dragoi Str., 310330 Arad, Romania; eugenia.tigan@uav.ro (E.T,.); oana.brinzan@uav.ro (O.B.) \\ * Correspondence: teodormateoc@usab-tm.ro (T.M.); anda_milin@yahoo.com or andamilin@usab-tm.ro (I.A.M.) \\ + These authors contributed equally to this work.
}

\section{check for}

updates

Citation: Mateoc-Sîrb, N.; Albu, S.; Rujescu, C.; Ciolac, R.; Tigan, E.; Brînzan, O.; Mănescu, C.; Mateoc, T.; Milin, I.A. Sustainable Tourism Development in the Protected Areas of Maramures, Romania: Destinations with High Authenticity. Sustainability 2022, 14, 1763. https:// doi.org/10.3390/su14031763

Academic Editors: Alina Badulescu and Vicky Katsoni

Received: 27 December 2021

Accepted: 31 January 2022

Published: 3 February 2022

Publisher's Note: MDPI stays neutral with regard to jurisdictional claims in published maps and institutional affiliations.

Copyright: () 2022 by the authors. Licensee MDPI, Basel, Switzerland. This article is an open access article distributed under the terms and conditions of the Creative Commons Attribution (CC BY) license (https:// creativecommons.org/licenses/by/ $4.0 /)$.

\begin{abstract}
Sustainable development involves economic growth in line with the requirements of ecological balance and human development, involving people's relations with the environment as well as the responsibility of the current generation over future generations. Sustainable tourism was designed and supported in an attempt to manage all resources, so that the economic, social, and aesthetic needs of an area are satisfied while maintaining cultural integrity, essential ecological processes, biological diversity, and life support systems. Sustainable tourism is not "a fashion"; it is a way of thinking and acting with long-term implications. At national level, we believe that Maramureş County, Romania, is one of the most gifted natural and socio-economic geographic areas in the Oriental Carpathians of Romania, in which the conditions of sustainable tourism can be met and supported long term. The purpose of this scientific paper is to identify, synthesize, process, and interpret data about the tourist qualification of some localities in the protected areas of Maramureş, so as to inform local decision-makers and tourists about tourism forms currently practiced (and) possibly practicable in the future, because since tourism, as an economic branch, leads to the growth of jobs, it can contribute to the sustainable development of the area. The mathematical model proposed in the paper allows the grouping of available resources from 25 settlements in order to establish the types of tourism that can be supported and developed in these localities.
\end{abstract}

Keywords: sustainable development; sustainable tourism; authenticity; tradition; Maramures County; Romania

\section{Introduction}

The World Tourism Organization (WOT) has supported this year's World Tourism Day on the topic "Tourism for inclusive growth" due to the fact that the human desire to travel and explore is universally valid. That is why tourism must be "open" to everyone for the social and economic benefits it brings [1]. Over the past three decades, tourism has become one of the most important developing industries. However, the European tourism industry is facing imported development gaps (though it has become profitable, it registers lower average receipts), which brings to the foreground finding models of improving competitiveness. On the other hand, in Europe, the aging of the population leads to an increase in the number of third-age tourists who are increasingly attracted by rural tourism 
and agritourism or other forms of tourism related to their concerns (religious, gastronomic, ecotourism, spa, etc.). Also, the interest in environmental and health issues is increasing, urban people take more frequent and short vacations and want their destinations to be easy to find and financially convenient. The number of those who want a quiet tourist area in an unpolluted environment is also increasing, especially in the current pandemic situation [2]. Under these conditions, WOT anticipates that Eastern Europe will become the main sub-regional destination, a good development opportunity for this segment in our country.

Tourism is one of the economic sectors that is directly related to major territorial development objectives: sustainable development (climate change, resource preservation), economic competitiveness at all levels (national, regional, local), social cohesion (community interaction between the locals and the tourists, access to tourism for disadvantaged categories), development of new technologies, etc. Tourism also contributes decisively to the reduction of urban/rural disparities, to the economic growth of areas in economic decline (peripheral areas, mountain areas, disadvantaged areas), and to the growth of territorial cohesion. Taking into account its specificity and importance, tourism needs to play an important role in Romania's new economic configuration.

The importance of tourism in the Romanian economy, in the future, can be marked by the following aspects: it catalyzes other economic sectors downstream and upstream (multiplier effect), absorbs some of the labor force, is one of the few sectors that cannot relocate, represents the best form of export (incoming = financial resources), generates a positive image for Romania, has positive social effects on local population (health state, mood), increases the sense of belonging to national values, and maintains the link between Romanians everywhere [3].

Until 2030, the authorities in the field intend to transform Romania into a high-quality and well-known tourist destination available year-round, capitalizing on the uniqueness of cultural and natural heritage and providing services at international standards. Such strategic indicators as foreseen by the National Strategy of Romania for the Development of Tourism 2019-2030 [3] are included in Table 1:

Table 1. Strategic indicators and foreseen results (2020-2030).

\begin{tabular}{ccccc}
\hline Strategic Indicators & $\mathbf{2 0 1 7}$ & $\mathbf{2 0 2 0}$ & $\mathbf{2 0 2 5}$ & $\mathbf{2 0 3 0}$ \\
\hline International incoming tourists (thousands) & 2.760 & 3.674 & 5.916 & 10.354 \\
\hline International tourism receipts (millions of Euros) & 1.314 & 1.796 & 3.360 & 6.554 \\
\hline Mean expenses per arrival (Euros) & 476 & 496 & 568 & 633 \\
\hline Increase of mean tourist stay from target-markets (days) & 2 & 2 & 2 & 3 \\
\hline Number of employees in tourism & 209.575 & 278.978 & 449.219 & 786.210 \\
\hline Share of GDP (\%) & 2.79 & 1.70 & 4.25 & 4.27 \\
\hline
\end{tabular}

Source: Data processing after [3].

Romania's Territorial Development Strategy has established three long-term national targets [4] (Horizon 2035) in the field of tourism:

(1) Diversification and specialization of the tourist offer, together with increase of service quality, concentration of infrastructure investments, and the re-qualification of degraded tourist areas;

(2) Active national and international promotion of Romanian tourism, in particular rural, ecological, and cultural tourism for the use of the variety of rural landscapes, of the persistence of traditional activities, of traditional gastronomy, and of the cultural offer of the neighboring urban centers;

(3) Training and qualification of specialized personnel, accreditation and records of specialized structures to ensure the quality and competitiveness of specific tourism services. 
In this context, tourism actors have to find effective solutions leading to the growth of tourism activities in Romania. Five rural and agritourist areas are recognized in Romania [2]: Maramureş, Bran-Moieciu, Bucovina, Mărginimea Sibiului, and the Apuseni Mountains. Each area has its own features and attractions, but they also have common features, such as special natural landscapes and authentic of rural areas, unprecedented in other areas of Europe $[5,6]$. The geographical location of Romania, with the most diverse landforms, with very varied climatic conditions, determines a great variety of habitats, which determines a unique diversity in Europe of five biogeographical regions, generating an abundance and diversity of plant and animal species. This abundance is reflected in a large spectrum of natural resources valuable for touristic potential. Maramureş County is a geographic area endowed with various natural tourist resources, yet (still) inadequately capitalized.

Among these are protected natural areas, which, through location and diversity, have become an important pillar of sustainable tourism development in the area. Tourism is an important activity that can solve some of the economic problems of protected areas that face restrictions in the development of certain investments and types of economic activities contrary to the preservation of the environment and to the conservation of natural and anthropogenic resources [7].

The more varied and complex resources, the higher the tourist interests, and the tourist activities they generate are more valuable and attractive, responding to many motivations of tourists [8]. Romania has a competitive advantage over other tourist destinations in this aspect, but it requires innovation in presenting this notion to the world, especially to potential tourists. As Jain [9] explained, any innovative idea that does not have a bit of emotion does not have the chance to have the desired impact.

\section{Literature Review}

Major environmental changes in the last 40 years have prompted population's awareness of the rapid evolution of risk elements that can affect the existence of mankind. Various world organizations (in the field of environmental protection but not only) have proposed fundamental changes in the lifestyle of the population, which resulted in the emergence of a new concept, namely "sustainable development" or "sustainability". The concept was initially regarded as an agreement between economic and social progress and the natural balance of the planet. Sustainable development was thought to be a solution to the ecological crisis determined by the powerful industrialization and inappropriate use of natural resources that have led to the continuous degradation of the environment [10].

As stipulated at the Rio de Janeiro World Conference in 1992, sustainable development is a form of economic development that ensures the satisfaction of the present consumption requirements without compromising or endangering those of the future generations. In its evolution, the notion of "sustainability" has gained multiple meanings: it has become a multidimensional concept (belonging to the concerns of economists, ecologists, sociologists, architects, lawmakers, local authorities, international and non-profit organizations) that has expanded in all spheres of activity (rural areas, tourism, environment etc.)

In this context, the need to identify appropriate development solutions needed by the specifics of rural areas has also emerged. The definition of the concept "sustainable rural development" started from the premise that the development of rural communities is a process in which communities are actively participating in the capitalization of their own resources for their complete economic and social benefit. This type of development supposes the existence of close links between rural community, government, and civil society. Sustainable rural development coordinates aim to raise the three functions of rural areas: economic, ecological, and socio-cultural. The three-dimensional relationship of rural space suggests that any action that takes place at a certain level can indirectly influence the other levels.

The concept of sustainable tourism and its implementation have been more and more debated in the last three decades because the complex link between environment and economy is evident. The need to integrate the two components involves ensuring premises 
for deep and lasting development with a positive impact on society as a whole [6]. The sustainable nature of tourism covers a wide range: the use of natural resources, assessment of the impact of tourist activities on the environment (waste generation and management, pressure on water, soil, and biodiversity, effect of global warming, use of "clean" energies), protection of heritage, preservation of the cultural integrity of destinations, permanence of jobs, positive impact on local economy, etc. So, one can speak of sustainability in an economic sense, in an ecologic sense, and in a cultural sense. All these aspects are largely reflected in the tourist strategies implemented at national, regional, and global level (even if they did not always have an actual purpose) [11-13].

Extant literature brings to the forefront various approaches to the sustainable tourism and regional development relationship, which is addressed in various scientific papers and statements from institutions with concerns in the field.

Over the last 35 years, many specialized publications, organizations, and institutions have been concerned with the field of sustainable tourism. An early document of these concerns is the Brundtland Report (1987), which refers to "Our common future" [14]. Five years later, in the United Nations Conference for Environment and Development framework, many important international environmental agreements have been laid: (for example-Agenda 21 and Rio Declaration on the Environment and Development). Other actions to support sustainable development and sustainable tourism are given by: Commission for Sustainable Development monitoring, enforcement of Agenda 21 (1993), World Conference for Sustainable Tourism-Lanzarote-Spania (1995), "Agenda 21 for Tourism and Travel Industry: towards sustainable tourism development" (1996), World Tourism Organization "Global Code of Ethics for Tourism" (2001), World Summit for Sustainable Development-South Africa (2002), Agenda for sustainable, competitive European tourism (2007), 2030 Agenda for Sustainable Development (2015), Resolution of European Parliament—developing a EU strategy for sustainable tourism (2021). Reports from various organizations came in support of sustainability-related actions: EUR-Lex and Basic Orientations for the Sustainability of European Tourism publications, Reports of the European Commission, The World Tourism Organization (WTO), The Travel \& Tourism Competitiveness Report, World Travel and Tourism Council (TSA Research), United Nations Environmental Program (UNEP).

Sustainable development and sustainable tourism have also been of interest to many researchers in the field since the 1990s. Among the first scientific papers in the field are related to the activity of Nash, Butler [15,16], and May [17]. After 2000, the preoccupations in this field became more and more intense. Economic literature has been enriched by multiple research publications: Sörensson and Friedrichs [18], Torres-Delgado. and López Palomeque [19], Tsung Hung Lee and Hsin-Pei Hsieh [20], Mustafa Rehman Khan, Haseeb Ur Rehman Khan, Chen Kim Lim, Kian Lam Tan 4, and Minhaz Farid Ahmed [21], Research in this area has also intensified in our country: Constantinescu I. [22], Ibanescu B.and Stoleriu O.M. [23], Sultan, M.T., Sharmin, F., Badulescu, A., Stiubea, E., Xue, K. [24], Ban O. and co-worker [25].

Changes in tourists' attitudes towards the need for sustainable tourism have been determined by a variety of factors (public pressure, environmental legislation, increased media coverage, and change in public opinion) $[26,27]$. Sustainable tourism needs "connection" with a number of principles of sustainable development and their application in all types of tourist activities; it includes all the segments of this industry, providing solutions to diminish the impact on the natural environment. The distinction between sustainable tourism and ecotourism should be punctuated due to the fact that is a lack of regulation regarding the ecotourism activity in Romania. Ecotourism can be defined as alternative tourism based on the natural environment. A component of sustainable tourism is an activity with minimum impact upon natural and socio-cultural environment. Ecotourism is a visiting experience where the main motivation is observation and appreciation of nature, and local culture that is discovered in natural areas, increasing the tourist's awareness on conservation of natural and anthropic resources. 
The natural protected area is a destination for ecotourism activities and is not allowed to make investments, like accommodation infrastructure into the natural protected area as ecotourism destination [28].

The concept of Ecotourism Destination was regulated by National Ecotourism Development Strategy in 2009 and was taken over in the version of the Strategy approved by Government Decision in 2019 (GD no. 358/2019). In order to receive the ecotourism destination status, an area has to accomplish a set of criteria, accordingly to Government Decision no. 358/2019 on approving the National Ecotourism Development Strategy [29].

Protected natural areas have become, both in terms of tourism consumers, researchers, and other stakeholders, holiday destinations based on the principles of sustainable development [30]. International scientific research in the field points to two main directions: (a) there is a high degree of awareness of the importance of developing and practicing forms of sustainable tourism-a positive aspect; (b) the offer comes partly to meet the demand for sustainable tourist consumption (such as that achieved in natural protected areas) - a negative aspect [31].

In order to develop tourism in protected areas, one needs to highlight the principles of ecotourism and the role of stakeholders (local communities and authorities, visitors, volunteers, landowners, residents, investors, non-governmental organizations, sports clubs, research bodies, educational institutions, cultural associations, media etc.) [32]. The forum that has as main objective solving difficult problems related to protected areas is the International Union for Conservation of Nature. (IUCN). Protected areas are terrestrial or maritime areas dedicated to the protection and maintenance of biological diversity and of associated natural and cultural resources, managed legally or otherwise [33]. Within protected areas, natural areas are preserved, where human intervention is almost non-existent, but also areas where human intervention is present, such as modified landscapes that are of particular landscape and cultural importance. Thus, protected areas, by their natural value and the low degree of human intervention, are the best examples and models for natural and semi-natural ecological systems, which, in turn, constitute the support of life and, implicitly, of socio-economic development. IUCN is trying to influence, encourage, and assist societies around the world in the process of preserving the integrity and diversity of nature, aiming at any use of natural resources to be fair and sustainable [34].

The purposes for which protected areas are managed are varied. Their management is related to scientific research, to the protection of the wild, to the protection of the diversity of species and genetic diversity, to the maintenance of services, to the protection of specific natural and cultural features, to tourism and recreation-education-sustainable use of natural ecosystem resources, and to the maintenance of cultural and traditional characteristics [35].

The responsibility for the management of protected areas is attributed to central, regional or local governmental and non-governmental organizations, to the private sector or to local communities. The condition is that the designated authority is able to meet management objectives. In practice, Category I-III protected areas are usually in the responsibility of a governmental body. Responsibility for categories IV and V is often attributed to local governments, which comply with the framework of national legislation [36].

For the existence and proper functioning of a national system of protected areas governments have a fundamental responsibility that they do not have to deviate. They must consider such a countries as important components of national conservation strategies and sustainable development $[37,38]$.

In the protection of ecosystems (through the practice of ecotourism), as part of the development of sustainable tourism, as an alternative form of tourism that is largely concerned with the economic, social and, most importantly, environmental impact of this sector, we must also consider more the role of ICT. Preserving the values of ecosystems in ecotourism destinations implies the need to constantly monitor the evolution of ecotourism and the associated impact in such destinations [39]. 
In order to preserve the biodiversity of Europe, Directive 92 [40], established the European Ecological Network "Natura 2000", which is the basis of nature conservation policy within the European Union, the structure of nature protection (not to be understood as "limitation and restriction"). Through this body, it is aimed to preserve natural habitats and wildlife species, the largest ecological network in the world, which establishes protected areas of community interest [41]. The objectives and advantages of this European Ecological Network are set out in Table 2.

Table 2. "Natura 2000"-Objectives and Advantages.

\begin{tabular}{|c|c|c|}
\hline Objectives & "Natura 2000" Sites & Advantages \\
\hline $\begin{array}{l}\text { - Stopping the decline of biodiversity } \\
\text { by long-term preservation of the most } \\
\text { valuable species and habitats of } \\
\text { community interest; } \\
\text { - Protecting Europe's biodiversity and } \\
\text { promoting beneficial economic activities. }\end{array}$ & $\begin{array}{l}\text { - Must include human activities } \\
\text { that are compatible with the } \\
\text { purposes of preservation; } \\
\text { - People need to understand, } \\
\text { through their own experience, } \\
\text { why a particular site is } \\
\text { worth protecting. }\end{array}$ & 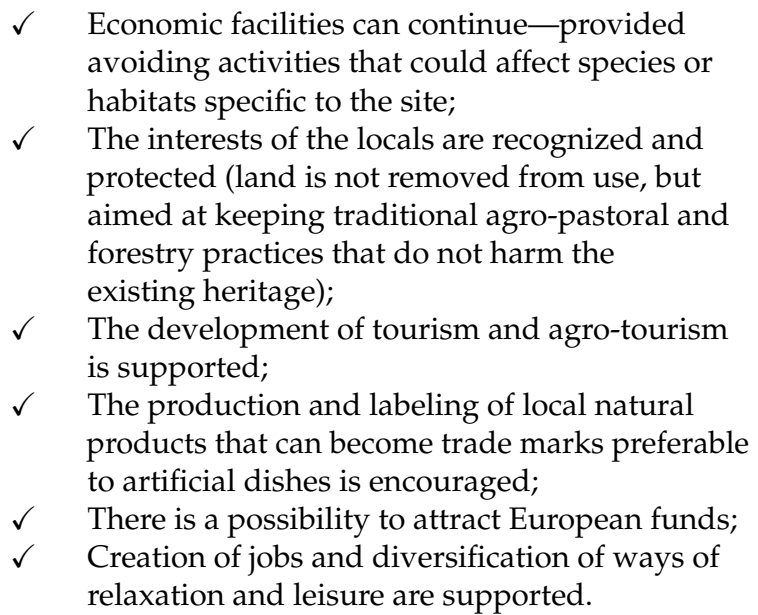 \\
\hline
\end{tabular}

Source: own construction based [41].

At European level, Romania has the most diversified and valuable natural heritage: the total protected natural areas of national interest, reported to the country's area, represents $7 \%$.

Natura 2000 sites have been designated specifically into the European Union to protect core areas for a sub-set of species or habitat types listed in the Habitats and Birds Directives. Based on scientific criteria, Natura 2000 Network choice of site could be:

- $\quad$ Sites of Community Importance (SCI) are natural areas which, in the region or biogeographical regions in which they exist, contribute significantly to maintaining or restoring to a favorable conservation status the natural habitats or species of Community interest;

- Special Areas for Conservation (SAC), aims are the conservation, maintenance and, where appropriate, the restoration of a favorable conservation status of the natural habitats and/or populations of the species for which the site is designated;

- SCI and SAC concern the same site, with differences of their level of protection. For SACs are necessary conservation measures are applied in order to ensure the conservation of the species and habitat types of EU importance present, national regulation need to establish the procedure of transition from SCI to SAC;

- $\quad$ Special Protection Areas (SPA), aims are the conservation, maintenance and, where appropriate, the restoration of a favorable conservation status of bird species and specific habitats designated for the protection of wild migratory bird species [42]. In Romania, we have declared:

$\checkmark \quad$ Natural areas of international interest: Biosphere Reserves-Danube Delta (1991), Retezat (1979), Pietrosul Rodnei (1979);

$\checkmark \quad$ Wetlands of international importance-Danube Delta (1991), Insula Mică a Brăilei (2001), Lunca Mureşului (2006), Complexul Piscicol Dumbrăviţa (2006), Techirghiol Lake (2006);

$\checkmark \quad$ Natural sites of the universal natural heritage-Danube Delta; 
$\checkmark \quad$ Geoparks-Geopark of dinosaurs in Ţara Haţegului, Geopark Mehedinţi Plateau (designated by GD 2151/2005 in the category of natural parks).

Under the national legislation in force, the categories of protected natural areas of national interest are: scientific reserves, national parks, natural monuments, nature reserves, and natural parks. Protected natural areas can be assigned in custody or may have their own administration structures, according to Romanian legislation [43-48].

"Natura 2000" allows both conservation and further development of Romania's biodiversity. At the same time, it leaves open ways of action in sustainable tourism directions (as well) and a combination of agricultural activities and nature protection alternatives.

\section{The Aim of the Paper}

The paper aims at establishing sustainable development of tourism activities in the protected areas in Maramures using the potential of the diversity of available resources in the area for the sustainable and balanced development of rural communities, on the one hand, and for the conservation and consolidation of territorial identity in an international context, on the other hand. The purpose of the paper is to identify the types of tourism that can be carried out in the protected areas of Maramures, depending on the available natural and anthropogenic resources and the tourist objectives of the area, in order to develop a sustainable economy of the area.

The specific objectives of present research are subordinated to the aim pursued: Objective 1: Highlighting the Maramureş area as a unique tourist destination in Romania and the world; Objective 2: Identifying localities in protected areas and natural and anthropogenic resources of Maramureş as important tourist destinations with high authenticity and opportunities for development; Objective 3: Identifying types of tourism that can be practiced in the (selected) locations in the protected areas of Maramureş County, in order to attract a growing number of tourists in the area with positive effects on future economic growth.

\section{Materials and Methods}

As regards the research methodology, the paper starts with research of secondary sources that includes several methods and techniques specific to the proposed objectives. The first part presents a bibliographic study based on literature. In this respect, several steps were taken: information in terms of sources, data collection, analysis of documentation sources and their grouping, in-depth assessment and study in order to achieve the proposed objectives. The last stage of scientific documentation consisted in using sources to prepare studies and analyses needed for research. The main method used is the content analysis, as well as the comparative method, used to highlight the issues, concepts, or notions.

To achieve the following objectives, we combined scientific documentation with direct documentation in the field, which allowed the analysis of practical reality on the subject and on the field of the research topic, respectively. In conducting the field research we used the method of partial observation (based on survey), carried out with the support of local authorities.

The direct survey (oral, face to face) was conducted in the town halls of the identified localities, due to the multiple advantages of the method: it provides results in a shorter time because the survey is more operational; the volume of material, human and financial resources involved is low, creates a facility for data collection, control and processing and recording errors are easier to identify and research in the validation phase of primary data, has the lowest rate of partial non-responses due to this operator.

The questions addressed to the competent persons were simple and clearly structured, with reference to the existence of resources and tourist objectives in each of the 25 localities investigated. Each question was provided with three answers: (1) no, (2) one, (3) several. The oral survey was conducted during 2021, by one of the co-authors of this study, in accordance with the experience gained in doctoral studies and who, in addition, knows the area, being his area of residence. Indirect observation was also used, based on derived sources. 
Sustainable development of rural areas through rural tourism is based on the assessment and monitoring of the tourist potential of the research area, starting from the classification of tourist resources and objectives [49]. In this sense we built a model for the evaluation of the tourism potential in the research, based on which a number of rural localities (villages) noted with $V_{j}$ were analyzed, where $j=1, \ldots, n$ is the number of villages. Locations are in a touristic area (TA).

Regarding the possible types of tourism practiced $\left(\mathrm{T}_{\mathrm{i}}\right)$, they are in a number " $\mathrm{m}$ " and thus $=1, \ldots, \mathrm{m}$. The scoring convention used is $T_{i}=0$, for the type of tourism with the current " $\mathrm{i}$ " number non-existing in that location, $\mathrm{T}_{\mathrm{i}}=1$, for the type of tourism " $\mathrm{i}$ " that provides tourists the potential of the type of tourism 1 (minimum rating), $T_{i}=2$, for the type of tourism " $\mathrm{i}$ " that has the potential of the type of tourism 2 (maximum rating). These three classes allow classifying the type of tourism, through the potential of the tourist destination that the destination can offer.

In agreement with these notations, there is $\mathrm{T}_{\mathrm{ij}}$ as the type of tourism " $\mathrm{i}$ " practiced at the level of the locality " $\mathrm{j}$ ". Tourist potential is then noted with $\mathrm{P}$, more precisely of a rural/urban locality $-\mathrm{P}\left(\mathrm{V}_{\mathrm{j}}\right)$ of the tourist area- $\mathrm{P}(\mathrm{TA})$, respectively.

The algebraic formula of the value defining the potential of rural locality " $\mathrm{j}$ " is:

$$
\mathrm{P}\left(\mathrm{V}_{\mathrm{j}}\right)=\mathrm{T}_{1 \mathrm{j}}+\mathrm{T}_{2 \mathrm{j}}+\ldots+\mathrm{T}_{\mathrm{mj}}=\sum_{\mathrm{i}=1}^{\mathrm{m}} \mathrm{T}_{\mathrm{ij}}
$$

Moreover, by summing up the values of the potential of the localities that make up the tourist area, the value of the tourist area is calculated (tourist area):

$$
P(T A)=P\left(V_{1}\right)+P\left(V_{2}\right)+\ldots+P\left(V_{n}\right)=\sum_{j=1}^{n} P\left(V_{j}\right)=\sum_{j=1}^{n} \sum_{i=1}^{m} T_{i j}
$$

The group of the values $\left\{\mathrm{P}\left(\mathrm{V}_{1}\right), \mathrm{P}\left(\mathrm{V}_{2}\right), \ldots, \mathrm{P}\left(\mathrm{V}_{\mathrm{n}}\right)\right\}$ thus allows a hierarchy of rural localities by potential by decreasing order $P\left(V_{j}\right), j=1, \ldots, n$. Of interest is the determination of the local tourist potential, namely the highest value in the group, $\underset{j=1, \ldots \mathrm{n}}{\max } \mathrm{P}\left(\mathrm{V}_{\mathrm{j}}\right)$. Thus, the values $T_{\mathrm{ij}}$ can be centralized in tabular. The way of centralizing the information is presented in Table 3.

Table 3. The values of the resources/types of tourism related to rural localities.

\begin{tabular}{cccccc}
\hline & \multicolumn{5}{c}{ Tourism Type “i” } \\
\hline Rural Locality “ $\mathbf{j}$ " & $\mathbf{1}$ & $\mathbf{2}$ & & $\mathbf{m}$ & Total \\
$\mathbf{1}$ & $\mathrm{T}_{11}$ & $\mathrm{~T}_{21}$ & $\ldots$ & $\mathrm{T}_{\mathrm{m} 1}$ & $\mathrm{P}\left(\mathrm{V}_{1}\right)=\sum_{\mathrm{i}=1}^{\mathrm{m}} \mathrm{T}_{\mathrm{i} 1}$ \\
$\mathbf{2}$ & $\mathrm{T}_{12}$ & $\mathrm{~T}_{22}$ & $\ldots$ & $\mathrm{T}_{\mathrm{m} 2}$ & $\mathrm{P}\left(\mathrm{V}_{2}\right)=\sum_{\mathrm{i}=1}^{\mathrm{m}} \mathrm{T}_{\mathrm{i} 2}$ \\
& $\ldots$ & $\ldots$ & $\ldots$ & $\ldots$ & \\
$\mathbf{n}$ & $\mathrm{T}_{1 \mathrm{n}}$ & $\mathrm{T}_{2 \mathrm{n}}$ & $\ldots$ & $\mathrm{T}_{\mathrm{mn}}$ & $\mathrm{P}\left(\mathrm{V}_{\mathrm{n}}\right)=\sum_{\mathrm{i}=1}^{\mathrm{m}} \mathrm{T}_{\mathrm{in}}$ \\
\hline
\end{tabular}

Source-Own construction according to the built model.

Tabular calculation and statistical indicators in numerical variant and graphics (see results) was performed using Microsoft Excel and JASP 0.16 [50].

\section{Results and Discussion}

\subsection{Maramureş Area as a Place of Research for the Sustainable Development of Tourism in Protected Areas}

Maramureş County is located in the northern part of Romania and stretches over an area of $630,436 \mathrm{~km}^{2}$. The location of Maramures county on the territory of the country is shown in the Figure 1. From the total area of the county, the mountain area covers $43 \%$, hills and plateaus cover $30 \%$, and depressions, terraces, and meadows cover $27 \%$. 


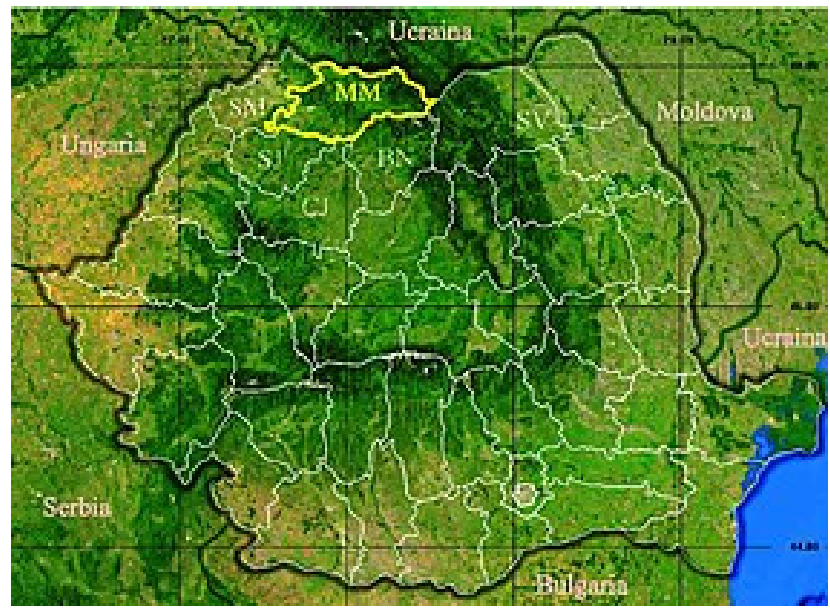

Figure 1. Maramureş County on the map of Romania. Source: processing after [51].

One of the main assets of the county are forests-total area of the forest fund is 263,895 ha, of which 257,385 ha are forests. The geographical and demographic characteristics of the county are summarized in Figure 2.

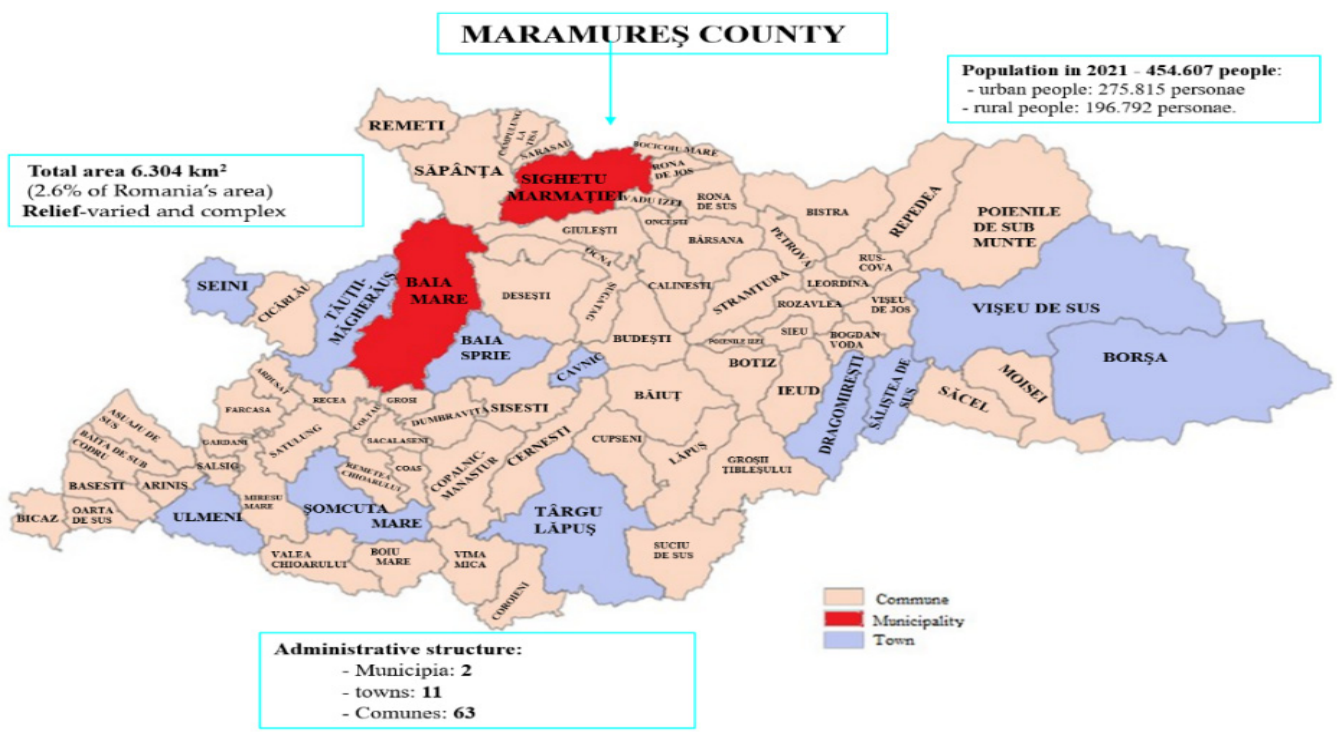

Figure 2. Maramures County: main physic-geographical and demographical features. Source-own construction based on [52]. Note: Towns is the urban administrative-territorial unit, characterized by a high population density and which concentrates socio-cultural activities and predominantly nonagricultural economic activities. Cities that have a larger number of inhabitants, a special economic, social and cultural significance at county or national level can be declared municipalities. Communes is the rural administrative-territorial unit, characterized by a lower population density, united by a community of interests and traditions, within which predominantly agricultural activities are carried out. Communes comprise one or more villages [53].

Maramureş County has a rich and diversified range of natural, socio-cultural, and economic resources, a rich history, a folk outfit, way of speaking, folklore, gastronomy, specific customs and specific popular dress, rich traditions transmitted from generation to generation, which, all, turns it into a unique global area. Tourism is the most appropriate transfer tool for well-being and job creation for this area, but it is known that the uncontrolled development of tourism can cause considerable inconveniences for tourist destinations and serious problems for natural resources. 


\subsection{Tourism in Maramures: Best Known Tourism Destinations}

For a better understanding of the tourist potential of the area, the diversity of destinations and tourist attractions, their location on the territory of the county, it is necessary to synthesize them-which is included in Table 4.

Table 4. Authentic tourism destinations in Maramures.

\begin{tabular}{|c|c|}
\hline Place & Particularities \\
\hline 1. Merry Cemetary from Săpânța & $\begin{array}{l}\text { One of the most famous tourist attractions in Maramureş, recognized abroad for its uniqueness } \\
\text { and for the note of optimism and joy it gives on death perception. }\end{array}$ \\
\hline 2. Bârsana Monastery & $\begin{array}{l}\text { Located } 22 \mathrm{~km} \text { southeast of Sighetul Marmaţiei, it is one of the reference objectives in } \\
\text { Maramures. The church of Barsana Monastery is one of the highest wooden churches in } \\
\text { Romania ( } 57 \mathrm{~m} \text { in height) (included in the UNESCO heritage) }\end{array}$ \\
\hline $\begin{array}{l}\text { 3. Valea Vaserului } \\
\text { forestry railway }\end{array}$ & $\begin{array}{l}\text { Since 2007, Valea Vaserului is part of the "Maramureş Mountains" Natural Park under } \\
\text { European protection. The Valea Vaserului forestry train is one of the most famous tourist points } \\
\text { in Romania. Annually, thousands of tourists travel by it, being declared in } 2013 \text { the tourism } \\
\text { objective of the year. }\end{array}$ \\
\hline 4. Cailor Waterfalls & $\begin{array}{l}\text { It is located near the tourist resort Borşa, in the northeastern part of the Rodnei Mountains. The } \\
\text { water gathered in a glacial circus runs over a steep limestone called "The Horses' Bridge", in } \\
\text { several steps, resulting in the largest waterfall in Romania. It is at an altitude of } 1300 \mathrm{~m} \text { and the } \\
\text { waterfall is } 90 \mathrm{~m} \text { high. The waterfall is accessible from several directions, from the } \\
\text { Borşa-Complex with the chairlift, or on foot, or from the higher areas of the Rodnei Mountains. }\end{array}$ \\
\hline 5. The town of Sighetu Marmatiei & $\begin{array}{l}\text { The Memorial of Victims of Communism and Resistance, known as the Sighet Pain Memorial. } \\
\text { "Maramureşean Village Museum" (outdoor museum) is a reservation of peasant architecture } \\
\text { monuments, aimed at recreating a zonal village with houses and households grouped on the } \\
\text { main subzone of historical Maramureş; } \\
\text { "Maramureş Ethnographic Museum"; } \\
\text { the Reformed Church (14th century), which is the highest building in the city (about } 60 \mathrm{~m} \text { ); } \\
\text { Maramureş County Building, Museum of Culture and Jewish Civilization, the Holocaust } \\
\text { Monument, the Jewish Synagogue, the Museum "Dr. Ioan Mihalyi de Apta". }\end{array}$ \\
\hline 6.The municipium of Baia-Mare & $\begin{array}{l}\text { Stephen's Tower, Citadel Square, Freedom Square, Evangelical Church, Butchers' Bastion, } \\
\text { Museum of History and Archeology, Museum of Ethnography and Folk Art, Planetarium, } \\
\text { Museum of Mineralogy. }\end{array}$ \\
\hline 7. Folk craftsmen & $\begin{array}{l}\text { Wood processing in Maramureş covers joinery, cooperage, carpentry, shingling, pottery, all } \\
\text { related to the surrounding woods, were usually passed from generation to generation or } \\
\text { learned by apprenticeship. } \\
\text { Tailoring was, in historic Maramureş, a male craft; tailors were sewing furs, vests, and wool } \\
\text { clothes, but also tight peasant trousers_-man pants-and they also applied ornamentation, a } \\
\text { scrupulous work, which demanded patience and much skill. } \\
\text { Spinning and weaving and rituals designed to chase away bad spirits (female activities). }\end{array}$ \\
\hline 8. Folk outfit & Numerous notes of sobriety, beauty, and incontestable seniority. \\
\hline
\end{tabular}

\subsection{Available Accommodation in Maramures,}

All over Maramureş, there are accommodation for all tastes and economic power of tourists from villas, chalets, and cottages, up to tourist, agritourist boarding houses and hotels with different degrees of comfort. The segments that have developed over the last 10-15 years are those of rural tourist boarding houses and that of agro-touristic boarding houses, which combine the specific Romanian hospitality with the traditions and customs of the area. The statistical interpretation of the data provided at county and national level indicates the following developments in this segment. The evolution of accommodation units and the number of tourists in Maramures County are summarized in the Figures 3-6. 

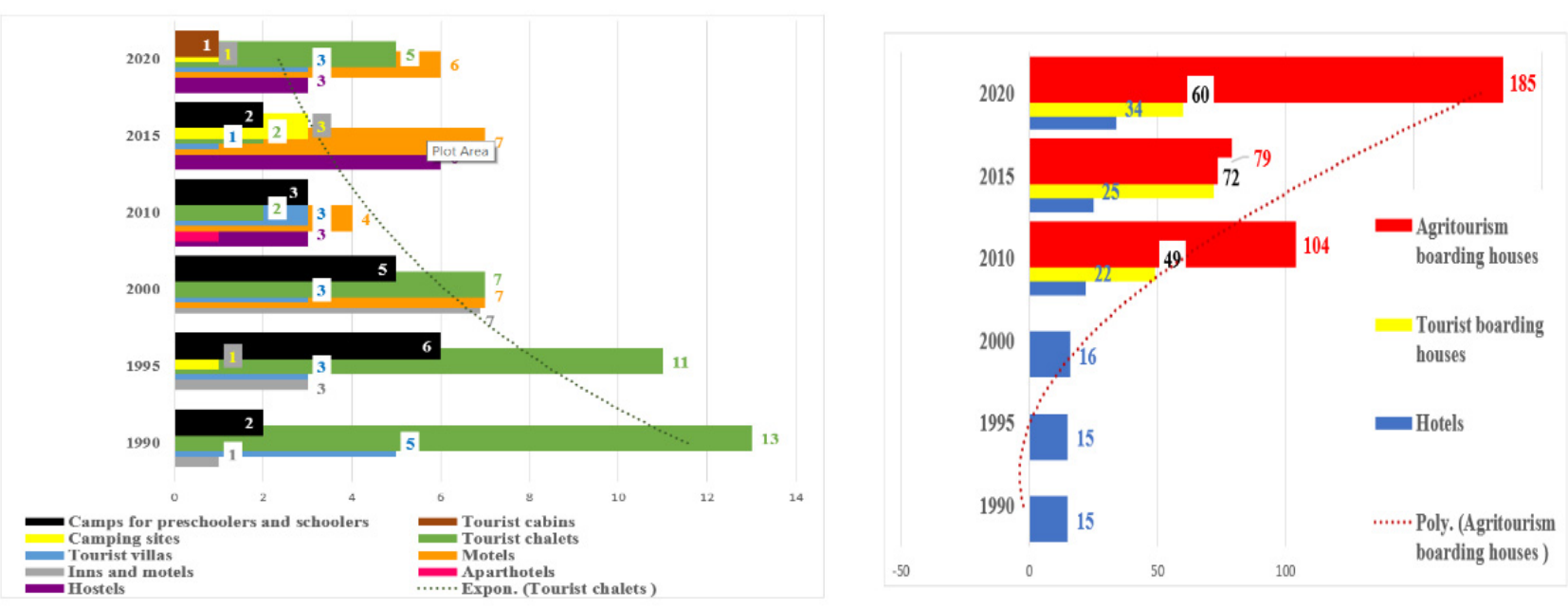

Figure 3. Number of accommodation spaces in Maramureș. Source-own construction after [55].
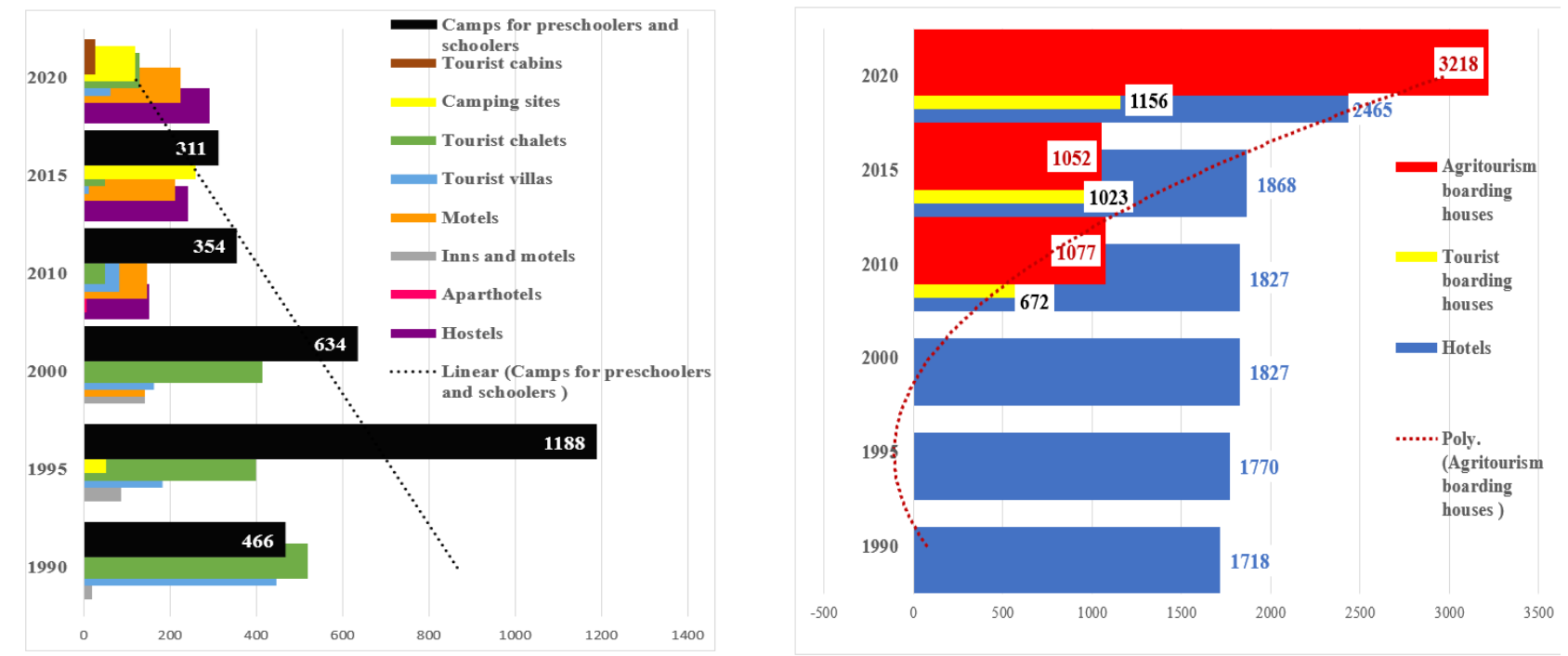

Figure 4. Number of accommodation places in Maramureș. Source-own construction after [55]..
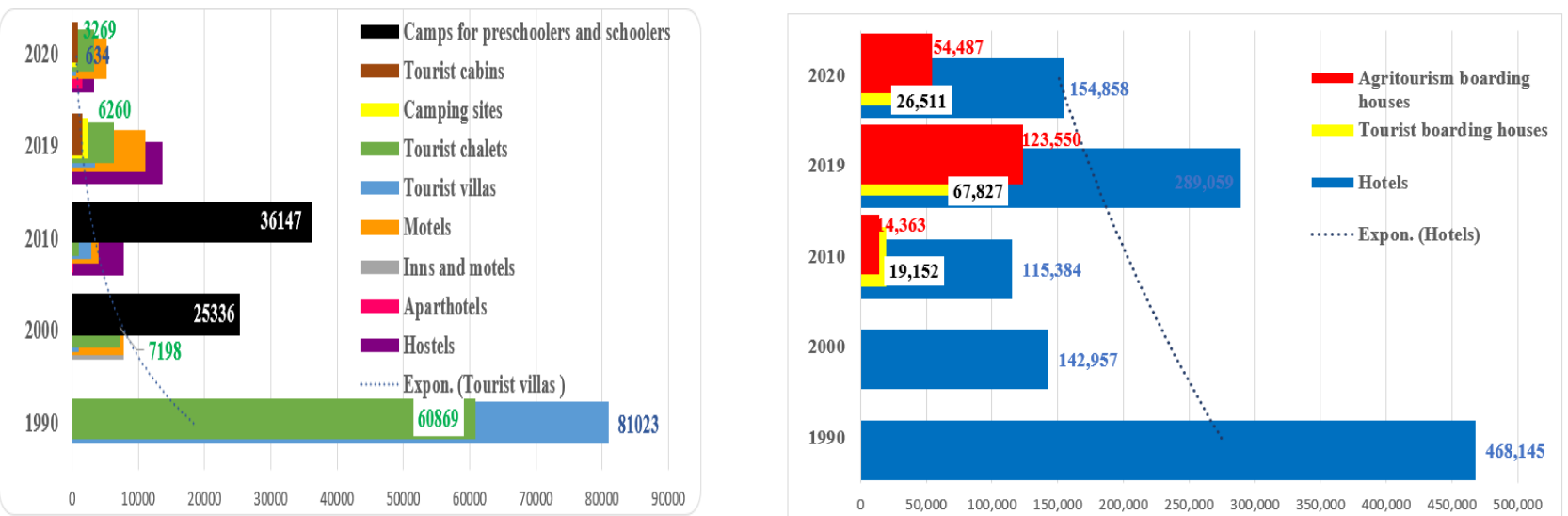

Figure 5. The evolution of overnight stays in reception structures, by types of structures in Maramures. Source-own construction after [55]. 

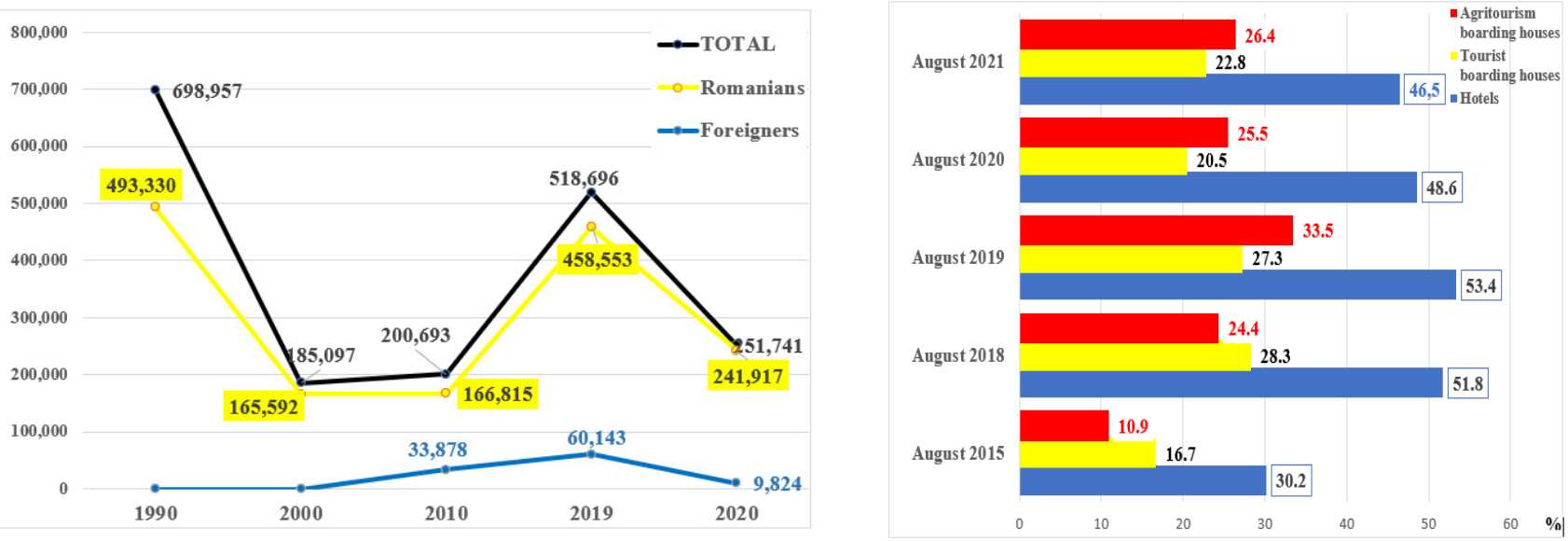

Figure 6. Overnight stays in tourist structures by types of tourists in Maramures, (left); Accommodation capacity utilization index (right). Source—own construction after [55].

There is an increase in the number of overnight stays in the tourist reception structures for both foreign and Romanian tourists, with a slight decrease in 2020, because of the Covid-19 pandemic. The index of the use of accommodation capacity in agrotourism, rural tourism and hostels has increased substantially in the last six years.

\subsection{Identification of Protected Areas in Maramures,}

In order to ensure special measures for the protection and conservation in situ of the natural heritage assets, accordingly to national regulation in Romania, a differentiated regime of protection, conservation and use is established, to the following categories of protected natural areas:

- of national interest: scientific reservations, national parks, natural monuments, natural reserves, natural parks;

- of international interest: natural sites of the universal natural heritage, geoparks, wetlands of international importance, biosphere reserves;

- of Community interest or "Natura 2000" sites: sites of Community importance, special conservation areas, special avifauna protection areas;

Depending of internal zoning and management plan, different economic activities are permitted, but as much as the protection interest is increasing, the economic activity impact need to decrease, or any human activity who is not compatible with the purpose of protection and/or conservation is forbidden. For most restrictive conservationist areas, education, research and ecotourism is permitted, because tourism and especially ecotourism though its function has an important role in awareness rising [43].

The total area of Maramureş County is 630,436 ha of which 164,290 ha are occupied by protected areas (over $26 \%$ of the county's area). In this county we have: one natural park and one national park, 18 natural monuments, 13 natural reserves, 3 scientific reserves, 3 local interest protected areas.

\subsection{Identification of Localities, Natural Resources, and Tourist Destinations in Protected Areas}

Identifying localities in protected areas, their resources, and sights was based on the content analysis of a rich bibliographic material and direct observations from the field [56-62]. Of the total number of the localities of the investigated area (246 urban and rural localities of the county), 25 localities located in protected areas, which have a tourist potential, have been identified. The position on the county map of the selected localities is included in Figure 7. All tourist attractions in Maramureş are part of the major classes of resources (attractions): natural and landscape, historical, spiritual-religious, ethnographic, or architectural, constituting particularly important and attractive tourist destinations for tourists, but constituting, at the same time, important resources for the sustainable 
development of the area. Many localities attract tourists through gastronomy and specific celebrations (Christmas, Easter, New Year, and other traditional celebrations), tourists being expected with traditional culinary products. One can say that a "current" has been created as young families with children choose to spend their holidays in this area [63-65].

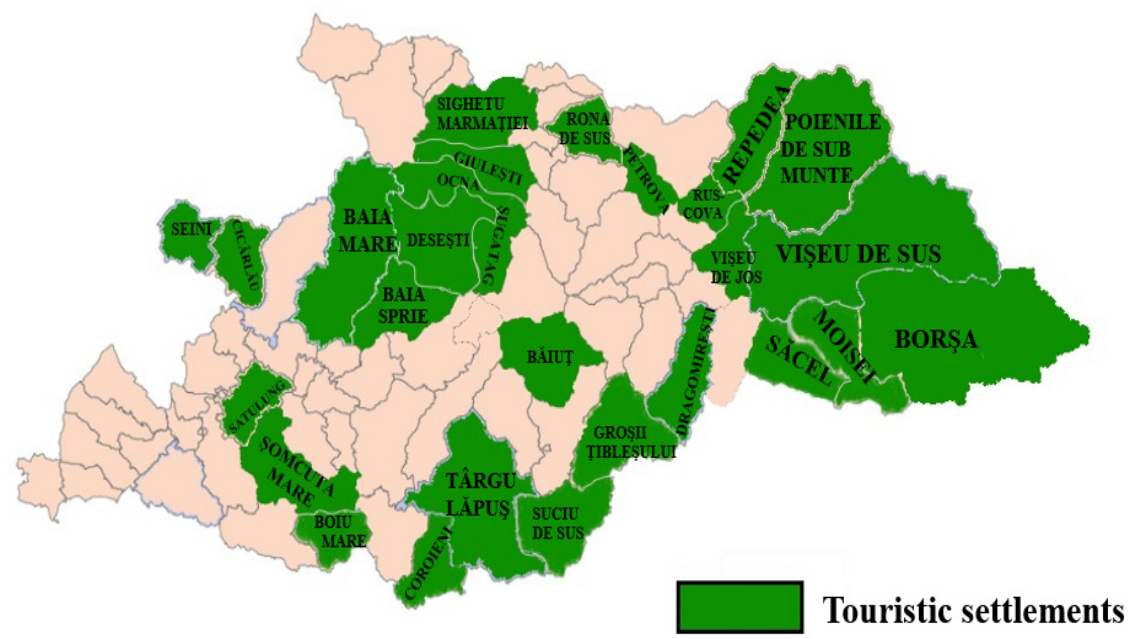

Figure 7. Settlements selected for study-identification within the county. Sources-processing according to the administrative map of the Maramureş County.

The aim of the study was to group the natural resources by localities, the direct implications of the study and the possible benefits being useful to the socio-economic environment. Following the field analyzes and researches, we synthesized the main resources, which can be, in each locality taken into consideration, sustainable development factors, the concrete result of the research giving us the possibility to systematically divide Maramures County into four "favorable" areas for practice. All these data are included in Table 5.

In the analysis of the natural and anthropic resources of Maramures County, the following specifications are required:

$\checkmark \quad$ the churches from Budești-Josani, Desești, Bârsana, Poienile Izei, Ieud Deal, Surdești, Plopiș and Rogoz, elements of the representative cultural heritage of Maramures, are included in the UNESCO world heritage;

$\checkmark \quad$ Maramureș county accomplished one of five Romanian ecotourism destination, MaraCosău-Creasta Cocoșului area, being supported by a local partnership between protected area administrators, local public authorities and non-governmental bodies, as Destination Management Organization;

$\checkmark \quad$ Maramures as touristic destination was rewarded by European Commission with four destinations of excellence by EDEN programme: Sighetu Marmației and Chioar Country for tangible cultural tourism, Ocna Șugatag and Tăuții Măgherăus, for health and relaxation tourism. This programme aims to sustain sustainable tourism be decreasing the negative impact on consecrated touristic destination and increasing the visibility of non-traditional destinations. Romania participated to all program competitions and prof that have a large potential for sustainable tourism.

4.6. Identification of Tourism Forms in Protected Area Localities of Maramureş-Which Can Contribute to the Development of the Locality

Identification of tourism forms was based on the mathematical model presented in the Material and Method section. Processing and synthesizing data collected from the field (from the 25 localities) allowed the making up of the following "present" tourism types in every settlements. The types of tourism identified in the research area is shown in Table 6. 
The scores obtained by the studied localities have values ranging from 9 (Giuleşti, Deseşti) to 16 for Borşa. The most common score is 12 which is also, at the same time, the median value of the series; $40 \%$ of localities have obtained the total score 12 . Score frequencies are shown in Table 7 below.

Table 5. Touristic settlements-natural and anthropic resource.

\begin{tabular}{|c|c|c|c|}
\hline Areas & $\begin{array}{l}\text { Settlements Included } \\
\text { in the Study }\end{array}$ & Natural Resources & Other Tipe of Resources \\
\hline \multirow{7}{*}{ 苛 } & (1) Borșa & $\begin{array}{l}\text { Cornu Nedeii-Ciungii Blăsinii, part of the } \\
\text { Maramures, Mountains Natural Park, Piatra Rea, } \\
\text { Stîncăriile Sălhoi-Zâmbroslavele, Pietrosu Mare (the } \\
\text { nature reserve is part of the Mountains Rodnei } \\
\text { National Park, declared protected area in } 2000 \text { and } \\
\text { covering } 3300 \text { ha, included in the UNESCO } \\
\text { programme "Man and Biosphere"), Izvorul Bătrâna, } \\
\text { a hydro-geological nature reserve (0.50 ha). }\end{array}$ & $\begin{array}{l}\text { Tourist Complex Băile-Borşa;the wooden } \\
\text { Church from Borșa din Jos (1700); } \\
\text { the Obelisk in Borşa (1717). }\end{array}$ \\
\hline & (2) Moisei & $\begin{array}{l}\text { Izvorul Bătrâna; Maramures, Mountains Natural Park; } \\
\text { National Park Rodnei Mountains; Nature Reserve } \\
\text { Cave and spring Izvorul Albastru al Izei: Cave from } \\
\text { Solovan Hill (a natural area declared natural } \\
\text { monument); IzaRiver Valley }\end{array}$ & $\begin{array}{l}\text { the Moisei Monastery; the wooden Church } \\
\text { "Adormirea Maicii Domnului" from the } \\
\text { Moisei Monastery (1672); Workshop and } \\
\text { oven of potterer Tănase Burnar }\end{array}$ \\
\hline & (3) Săcel & $\begin{array}{l}\text { Cave and spring Izvorul Albastru al Izei (a mixed } \\
\text { nature reserve); the Natural Park Maramures } \\
\text { Mountains; the Natural Park Rodnei Mountains; the } \\
\text { Nature Reserve Izvorul Bătrâna; the Cave from } \\
\text { Solovan Hill ; Peasant Water Mills in Săcel, Mountain } \\
\text { trails in Rodnei Mountains, Iza River Valley }\end{array}$ & the Church "St Apostoli Petru și Pavel" (1909) \\
\hline & (4) Vișeul de Jos & $\begin{array}{l}\text { Natural Park Maramures Mountains } \\
\text { Reserve Narcissus Clearing Tomnatec Sehleanu; } \\
\text { Protected natural area Peak Farcău } \\
\text { Lake Vinderel } \\
\text { Peak Mihailescu; }\end{array}$ & $\begin{array}{l}\text { Valea Morii, a partially electrified hamlet, } \\
\text { very authentic, which leads to Poienile de } \\
\text { Sub Munte and Valea Drăguiasa } \\
\text { the Church "St Ierarh Nicolae"; the Orthodox } \\
\text { Parish Vişeu de Jos "Înalțarea St Cruci"; } \\
\text { "Mocăniţa" on the River Vaser (the only } \\
\text { industrial train pulled by a steam } \\
\text { locomotive in Europe still operating) }\end{array}$ \\
\hline & (5) Vișeul de Sus & $\begin{array}{l}\text { Natural Park Maramures Mountains } \\
\text { Vaser Valley and Mocăniţă } \\
\text { Vişeu Valley, } \\
\text { Iza Valley }\end{array}$ & $\begin{array}{l}\text { Cartierul Tipterai-the neighbourhood of } \\
\text { German colonists; } \\
\text { theDocumentary-Exhibition Centre of } \\
\text { Maramures, Romanian Nobility; the } \\
\text { Museum-House "Elefant"-the last } \\
\text { traditional Jewish wooden house; the } \\
\text { Hermitage "Naşterea Maicii Domnului" } \\
\text { from Valea Scradei (1762); the Orthodox } \\
\text { Church "Buna Vestire" (1834); the Museum } \\
\text { of Ethnography and History and the Crafts } \\
\text { Centre; the Roman-Catholic Church Ioan şi } \\
\text { Ana (1812); the Jewish Cemetery }\end{array}$ \\
\hline & (6) Petrova & Natural Park Maramureș Mountains & $\begin{array}{l}\text {-old house and wooden gates;Bulbucilor } \\
\text { Festival", a folklore festival }\end{array}$ \\
\hline & (7) Ruscova & $\begin{array}{l}\text { Natural Park Maramures, Mountains } \\
\text { Ruscovei Valley and Dragmirov Valley }\end{array}$ & $\begin{array}{l}\text {-the wooden Church "St Ierarh Nicolae" } \\
\text { from Oblaz; a synagogue; old houses and } \\
\text { typically Ukrainian folk outfit, rafting } \\
\text { downstream, mountain climbing; hiking; } \\
\text { folk craftsmen }\end{array}$ \\
\hline
\end{tabular}


Table 5. Cont.

\begin{tabular}{|c|c|c|c|}
\hline Areas & $\begin{array}{l}\text { Settlements Included } \\
\text { in the Study }\end{array}$ & Natural Resources & Other Tipe of Resources \\
\hline$\ddot{\dot{Z}}$ & $\begin{array}{l}\text { (8) Poienile de sub } \\
\text { Munte and Repedea }\end{array}$ & $\begin{array}{l}\text { protected natural area Peak Fărcău-Lake Vinderelu-Peak } \\
\text { Mihăilescu included in the Natural Park Maramureșului } \\
\text { Mountains; the reserve has a glacier relief (Groapa } \\
\text { Julii, Groapa Lupilor, Groapa Bologhii, Farcău), rocky } \\
\text { ravines, meadows, patches of forest and meadow; } \\
\text { Narcissus Clearing Tomnatec-Sehleanu River } \\
\text { Repedea; River Ruscova; Lake Vinderel, Gorges } \\
\text { Scărişoara, Valea Cvasniț, Zakira; Gruni or Elea } \\
\text { Herbari from Pentaya; Gura Ricii or Belen host gaseous } \\
\text { mineral water springs; cave Pentaya-Soloteanei, cave } \\
\text { on the Menciul Mountain and cave Bursucina. }\end{array}$ & $\begin{array}{l}\text { Church "Înălţarea lui Hristos", the } \\
\text { museum-church from Poienile de Sub } \\
\text { Munte, the Ukrainian wooden Church } \\
\text { "Inăltarea Domnului" from Poienile de sub } \\
\text { Munte (1798); the Orthodox Ukrainian } \\
\text { Church (1901); the mountain chain }\end{array}$ \\
\hline \multirow{5}{*}{ そֶ. } & $\begin{array}{l}\text { (1)Sighetu } \\
\text { Marmației }\end{array}$ & $\begin{array}{l}\text { Cave from Solovan Hill; the archaeological site } \\
\text { Solovan Hill; the archaeological site Valea Mare, } \\
\text { River Iza Valley. }\end{array}$ & $\begin{array}{l}\text { Church "Adormirea Maicii Domnului" (1892); } \\
\text { the Reformed Church (14th century); the } \\
\text { Church St Carol de Borromeo" (1730-1806); } \\
\text { the Ukrainian Church "Înăltarea Sfintei } \\
\text { Cruci" (1792-1807); the Synagogue (1902), } \\
\text { as well as the Ethnographic Museum of } \\
\text { Maramureș; the Museum of Maramures, } \\
\text { Village; the Museum of Jewish Culture; the } \\
\text { Prison, today the Museum of the victims of } \\
\text { communism and of anti-communist } \\
\text { resistance from Sighet (1897); the } \\
\text { Museum-House "Dr Ioan Mihalyi de Apșa"; }\end{array}$ \\
\hline & (2) Rona de Sus & $\begin{array}{l}\text { larix forest at Costiui and Forest Ronisoara (both } \\
\text { forestry nature reserves) }\end{array}$ & $\begin{array}{l}\text { the Roman-Catholic Church "St Ioan" from } \\
\text { Costiui (1807-1812); the Orthodox } \\
\text { Monastery "Adormirea Maicii Domnului" } \\
\text { from Rona de Sus; the Church "Calvaria" } \\
\text { (1841-1842); the Greek-Catholic Church } \\
\text { from Costiui (1775); the Chapel "St Ana"; } \\
\text { the Chapel "Fecioara Maria" (1771); the } \\
\text { Apaffi Castle; the Monument of St Ioan de } \\
\text { Nepomuk" (patron of miners) (1742). }\end{array}$ \\
\hline & (3) Giulești & $\begin{array}{l}\text { Poiana Brazilor Marshes; "Tăul lui Dumitru”; Ignis, } \\
\text { Mountains }\end{array}$ & $\begin{array}{l}\text { the wooden Church "St Nicolae" from } \\
\text { Feresti (1700); the wooden Church of the } \\
\text { Monastery (17th century); the brick Church } \\
\text { "Adormirea Maicii Domnului" }\end{array}$ \\
\hline & (4) Ocna Sugatag & $\begin{array}{l}\text { Forest Crăiasa, Gutâi Mountains; the Nature Reserve } \\
\text { Lake Morărenilor ( } 20 \text { ha) }\end{array}$ & $\begin{array}{l}\text { the wooden Church "Cuvioasa Paraschiva" } \\
\text { from Sugatag (1642); the wooden Church } \\
\text { "Sts Arhangheli Mihail și Gavril" from } \\
\text { Hoteni (built in } 1790 \text { in Slatina, Ukraine, } \\
\text { and brought in } 1895 \text { to Hoteni); }\end{array}$ \\
\hline & (5) Baia Sprie & $\begin{array}{l}\text { two nature reserves: Blu Lake and the fossiliferous } \\
\text { Reserve Chiuzbaia; Gutâi Mountains }\end{array}$ & $\begin{array}{l}\text { the Orthodox Church "Adormirea Maicii } \\
\text { Domnului" (1793, historical monument); } \\
\text { the Orthodox Church "Sts Arhangheli Mihail } \\
\text { și Gavriil" from Satu Nou de Sus (1775); the } \\
\text { Roman-Catholic Church in Gothic style from } \\
\text { Tăutii de Sus (14th-15th century); the } \\
\text { Church "Sts Apostoli Petru și Pavel" from } \\
\text { Tăutii de Sus (1779); The Roman-Catholic } \\
\text { Church (1846-1858); the Jesuits' House } \\
\text { (16th-17th century); the Chapel "Calvaria" } \\
\text { (17th century); the Roman-Catholic parish } \\
\text { house (1773); the Orthodox parish house } \\
\text { (1836); the wooden House "Csaszi" (1754) } \\
\text { the former building of the Mines" Office } \\
\text { (1733), today Town Hall }\end{array}$ \\
\hline
\end{tabular}


Table 5. Cont.

\begin{tabular}{lll}
\hline Areas & $\begin{array}{l}\text { Settlements Included } \\
\text { in the Study }\end{array}$ & Natural Resources \\
\hline (6)Baia Mare & $\begin{array}{l}\text { Arborele de castan comestibil de la Baia Mare; } \\
\text { Coloanele de la Limpedea; Mlaștinile Vlășinescu; Tăul } \\
\text { lui Dumitru;the fossiliferous Reserve Chiuzbaia; the } \\
\text { Nature Reserve Mlaștina Iezerul Mare (0.5 ha); the } \\
\text { protected area Creasta Cocoșului (50 ha); Cheile } \\
\text { Tătarului; Gutâi Mountains; Igniș Mountains. }\end{array}$
\end{tabular}

Other Tipe of Resources

The Roman-Catholic Church "Tăierea Capului St Ioan" from Tăutii de Sus (14th century); The Reformed Church from Tăutii Măgherăuș (14th-15th century); The Church "St Anton" from Baia Mare (1402); the Roman-Catholic Church "St Lorinc" from Tăutii Măgherăus, (1875); the stone Church "Sts Apostoli Petru si Pavel" from Tăutii de Sus (1773); the Orthodox Church "Sts Arhangheli Mihail și Gavriil" (1885); the Cathedral Adormirea Maicii Domnului from Baia Mare (1905-1911); the Stefan Tower from Baia Mare (annexe of the cathedral "St Ștefan" built by Iancu de Hunedoara, 15th century); the Iancu de Hunedoara House from Baia Mare (1446, part of the old medieval castle built by Iancu de Hunedoara for his wife Elisabeta); the wooden Church "St Paraschiva" from Desesti (18th century,); the wooden Church "Naşterea Maicii Domnului" from Hărniceşti (1770); the Historic Centre from Baia Mare; the Agreement Area "Firiza",

(7) Băiuț Mlaștina Tăul Negru and the Bone Cave from Poiana the wooden Church "Sts Apostoli" from Poiana Botizii (1825); the stone Church "Sts Botizii; the Tăul Negru Marshes; Nature Reservewetlands that shelter a rich and diversified flora; mountain trails in Maramures, and Bucovinei mountains

(8) Breb natural area-Lake Morărenilor; Forest Crăiasa (44 ha); Nature Reserve by Gutâi Mountains

Church "Sts Arhangheli Mihail și Gavriil" from Breb (1622); the wooden Church "Cuvioasa Paraschiva" from Sugatag (1642); the wooden Church "Sts Arhangheli Mihail si Gavril" from Hoteni

(9) Desești Cheile Tătarului, Gutâi Mountains, Igniș Mountains, Creasta Cocosului; the Iezerul Mare Marshes (a floristic and faunistic nature at an altitude of $1014 \mathrm{~m}$ )

(1) Seini Pine Forest in Comja (a forest nature reserve located in the counties of Maramures, and Satu Mare, on the administrative territory of Seini -Rașca); the archaeological site "Berenaș"; Gutâi Mountains

the wooden Church "St Paraschiva" from Desești

\section{the stone Orthodox Church "Sts} Arhangheli Mihail și Gavriil" (1882); the Roman-Catholic Church "Neprihănita Zămislire" (1421); the former Romanian confessional school (1860-1865); the Reformed Calvinist Church (1796); a synagogue (1904); the Roman-Catholic confessional school (18th century); the Church "Adormirea Maicii Domnului" from Racșa (19th century);

(2) Cicârlău geological, palaeontological, and landscape Nature Reserve Rozeta de piatră from Ilba; Gutâi Mountains

the Orthodox Church "Sts Apostoli Petru si
Pavel" from Cicârlău (1911); numerous historical monument churches in Tăutii-Măgherăuș: the Orthodox Church "Sts Apostoli Petru și Pavel" (1560); the Roman-Catholic Church "St Lorinc" (1875); the Reformed Church (14th century); 
Table 5. Cont.

\begin{tabular}{|c|c|c|c|}
\hline Areas & $\begin{array}{l}\text { Settlements Included } \\
\text { in the Study }\end{array}$ & Natural Resources & Other Tipe of Resources \\
\hline & $\begin{array}{l}\text { (3) Satulung } \\
\text { and Fersig }\end{array}$ & Forest Bavna, Someșului Meadow. & $\begin{array}{l}\text { the wooden Church "Cuvioasa Paraschiva" } \\
\text { from Stejera (1700); the Orthodox Church } \\
\text { "Sts Arhangheli Mihail și Gavriil" from } \\
\text { Miresu Mare (1886); the Teleki Castle from } \\
\text { Satulung (1740-1780); the Geza Teleki } \\
\text { Castle from Pribilesti (19th century); }\end{array}$ \\
\hline & (4) Boiu Mare & $\begin{array}{l}\text { the Cave Boiu Mare (Natural Monument of } \\
\text { speleologic importance); the historical Region of } \\
\text { Tării Chioarului; the Cheile Lăpușului Nature } \\
\text { Reserve; the Cave from Vălenii Șomcutei; Agreement } \\
\text { area and hiking in Valea Lăpușului. }\end{array}$ & $\begin{array}{l}\text { the wooden Church from Frâncenii Boiului } \\
\text { (1780); the wooden Church from Codru } \\
\text { Butesii (1700); the wooden Church from } \\
\text { Vălenii Șomcutei (17th century). }\end{array}$ \\
\hline & (5) Somcuta Mare & $\begin{array}{l}\text { the protected area Cave of Vălenii Somcutei (a } \\
\text { speleologic nature reserve); the archaeological sites } \\
\text { "Valea lui Stefan" and "Ograda Budenilor" from } \\
\text { Vălenii Somcutei. }\end{array}$ & $\begin{array}{l}\text { the Orthodox Church "Sts Apostoli Petru și } \\
\text { Pavel" from Somcuta Mare (1862-1885); the } \\
\text { Roman-Catholic Church "St Vasile" from } \\
\text { Somcuta Mare (1895); the wooden Church } \\
\text { "Sts Arhangheli Mihail și Gavril" from } \\
\text { Vălenii Somcutei (17th century); the } \\
\text { wooden Church "Sts Arhangheli Mihail și } \\
\text { Gavril" from Codru Butesii (1700); the } \\
\text { Headquarters of the District Chioar (today } \\
\text { the headquarters of the gendarmerie), } \\
\text { (1861); the Small Rural District Court } \\
\text { (today the Law Court and Prosecutor's } \\
\text { Office of Șomcuta Mare) (19th century); }\end{array}$ \\
\hline \multirow[t]{3}{*}{ 芒 } & (1) Târgu Lăpuș & $\begin{array}{l}\text { the protected area Cheile Lăpușului; } \\
\text { the Nature Reserve "Cheile Babei" }\end{array}$ & $\begin{array}{l}\text { Wooden church "St Nicolae" from Boiereni } \\
\text { (1815); the Reformed-Calvinist Church from } \\
\text { Dămăcușeni (circa 1700); the wooden } \\
\text { Church "Sts Arhangheli Mihail și Gavril" } \\
\text { from Dumbrava (18th century); the wooden } \\
\text { Church "St Maria" from Fântânele (1900); } \\
\text { the wooden Church "Sts Apostoli" from } \\
\text { Groape (1830); the wooden Church "Sts } \\
\text { Arhangheli Mihail și Gavril" from Inău } \\
\text { (1689); the wooden Church from Răzoare } \\
\text { (18th century, brought from Glod, Sălaj } \\
\text { County, after 1867); the wooden Church "St } \\
\text { Arhangheli" from Rogoz (1663); the Church } \\
\text { "Adormirea Maicii Domnului" from } \\
\text { Boroieni; the Rohia Monastery; the wooden } \\
\text { Church from Stoiceni (1860); }\end{array}$ \\
\hline & (2) Coroieni & Cheile Babei, Cheile Lăpuşului & $\begin{array}{l}\text { the wooden Church from Drăghia (1706); the } \\
\text { wooden Church "Sts Arhangheli Mihail și } \\
\text { Gavriil" from Dealu Mare (1875); the brick } \\
\text { Church "Nașterea Maicii Domnului" from } \\
\text { Vălenii Lăpusului (1813); from Dealu Mare- } \\
\text { Măgura (1707) }\end{array}$ \\
\hline & $\begin{array}{l}\text { (3)-(5) Dragomirești, } \\
\text { Groșii Țibleșului, } \\
\text { Suciu de Sus }\end{array}$ & $\begin{array}{l}\text { the protected area Acer-Tibles, Bran; } \\
\text { the Nature Reserve "Cave from Solovan Hill"; the } \\
\text { tourist area "Valea Izei". }\end{array}$ & $\begin{array}{l}\text { the wooden Church "St Dumitru" from } \\
\text { Larga (1771); the monk Monastery from } \\
\text { Dragomiresti; the Museum of Romanian } \\
\text { peasant woman from Dragomireşti; }\end{array}$ \\
\hline
\end{tabular}


Table 6. The types of tourism identified in the research area.

\begin{tabular}{|c|c|c|c|c|c|c|c|c|c|c|c|}
\hline \multicolumn{12}{|l|}{ Tourism Types “Ti" } \\
\hline Rural/Urban “ $\mathbf{V}_{\mathbf{j}}$ " & T1 & $\mathrm{T} 2$ & T3 & T4 & T5 & T6 & T7 & T8 & T9 & T10 & $\begin{array}{l}\text { Total Points } \\
\mathbf{P}\left(\mathbf{V}_{\mathbf{j}}\right)\end{array}$ \\
\hline V1 & 2 & 0 & 2 & 2 & 2 & 2 & 1 & 0 & 2 & 0 & 13 \\
\hline V2 & 2 & 2 & 1 & 2 & 2 & 2 & 2 & 0 & 2 & 0 & 15 \\
\hline V3 & 2 & 1 & 2 & 2 & 2 & 2 & 1 & 2 & 1 & 0 & 15 \\
\hline V4 & 2 & 1 & 0 & 2 & 2 & 2 & 0 & 2 & 1 & 0 & 12 \\
\hline V5 & 2 & 2 & 2 & 2 & 2 & 2 & 2 & 0 & 2 & 0 & 16 \\
\hline V6 & 2 & 1 & 2 & 2 & 2 & 2 & 0 & 0 & 1 & 0 & 12 \\
\hline V7 & 2 & 1 & 0 & 2 & 2 & 2 & 2 & 0 & 1 & 0 & 12 \\
\hline V8 & 2 & 1 & 0 & 2 & 2 & 2 & 0 & 0 & 1 & 0 & 10 \\
\hline V9 & 2 & 1 & 0 & 2 & 2 & 2 & 0 & 0 & 1 & 0 & 9 \\
\hline V10 & 2 & 1 & 0 & 2 & 2 & 2 & 0 & 0 & 1 & 0 & 10 \\
\hline V11 & 2 & 0 & 0 & 2 & 2 & 2 & 0 & 0 & 1 & 0 & 9 \\
\hline V12 & 2 & 2 & 0 & 2 & 2 & 2 & 0 & 0 & 2 & 0 & 12 \\
\hline V13 & 2 & 1 & 2 & 2 & 2 & 2 & 0 & 0 & 1 & 0 & 12 \\
\hline V14 & 2 & 2 & 0 & 2 & 2 & 2 & 0 & 0 & 1 & 0 & 11 \\
\hline V15 & 2 & 2 & 0 & 2 & 2 & 2 & 0 & 0 & 1 & 0 & 11 \\
\hline V16 & 2 & 1 & 2 & 2 & 2 & 2 & 0 & 0 & 1 & 0 & 12 \\
\hline V17 & 2 & 2 & 0 & 2 & 2 & 2 & 0 & 0 & 1 & 0 & 11 \\
\hline V18 & 2 & 0 & 2 & 2 & 2 & 2 & 0 & 0 & 2 & 0 & 12 \\
\hline V19 & 2 & 1 & 0 & 2 & 2 & 2 & 0 & 2 & 1 & 0 & 12 \\
\hline V20 & 2 & 1 & 0 & 2 & 2 & 2 & 0 & 0 & 1 & 0 & 10 \\
\hline V21 & 2 & 1 & 0 & 2 & 2 & 2 & 0 & 0 & 2 & 2 & 13 \\
\hline V22 & 2 & 1 & 0 & 2 & 2 & 2 & 0 & 2 & 1 & 0 & 12 \\
\hline V23 & 2 & 1 & 0 & 2 & 2 & 2 & 0 & 0 & 2 & 0 & 11 \\
\hline V24 & 2 & 2 & 0 & 2 & 2 & 2 & 0 & 0 & 2 & 0 & 12 \\
\hline V25 & 2 & 2 & 2 & 2 & 2 & 2 & 0 & 0 & 2 & 0 & 14 \\
\hline \multicolumn{11}{|c|}{ Total value of the tourist area $\mathrm{P}(\mathrm{TA})$} & 298 \\
\hline
\end{tabular}

NOTE: T1. Ecotourism; T2. Mountain tourism; T3. Spa tourism; T4. Rural tourism/agriturism; T5. Historic cultural tourism; T6. Religious tourism; T7. Mining tourism; T8. Cave tourism; T9. Hunting and fishing tourism. T10. Darktourism. V1 Baia Mare; V2 Baia Sprie; V3 Băiut; V4 Boiu Mare; V5 Borsa; V6 Breb; V7 Cicârlău; V8 Coroieni; V9 Desești; V10 Dragomirești, Groșii Țibleșului, Suciu de Sus; V11 Giulești; V12 Moisei; V13 Ogna Sugatag; V14 Poienile de sub Munte și Repedea; V15 Petrova; V16 Ruscova; V17 Rona de Sus; V18 Satu lung, Fersig; V19 Săcel; V20 Seini; V21 Sighetu Marmației; V22 Șomcuta Mare; V23 Târgu Lăpuș; V24 Vișeul de Jos; V25 Vișeul de Sus. Sources—own processing after mathematical model.

Table 7. Frequency of locality scores.

\begin{tabular}{ccc}
\hline Score & Frequency & Percent \\
\hline 9 & 2 & 8 \\
10 & 3 & 12 \\
11 & 4 & 16 \\
12 & 10 & 40 \\
13 & 2 & 8 \\
14 & 1 & 4 \\
15 & 2 & 8 \\
16 & 1 & 4 \\
Total & 25 & 100 \\
\hline
\end{tabular}

Source-Own calculations using JASP.

The mean value is 11.92 with a Standard Deviation 1.75. The amplitude of the series (Range) is 7 points. The statistical summary of the total score series attributed to the studied localities is displayed in Table 8. The Violin type diagram is used to describe the dissection of this series in Figure 8. Skewness is positive 0.53 and indicates only a slight asymmetry. Low scores of total scores appear with slightly higher frequency than high scores. The Kurtosis value is close to zero indicating a flattening of the distribution. A high number of extreme values compared to the average value frequency leads to this observation. 
Table 8. Statistic summary of scores in studied localities.

\begin{tabular}{cc}
\hline Mean & 11.92 \\
Median & 12 \\
Mode & 12 \\
Standard Deviation & 1.754 \\
Sample Variance & 3.076 \\
Kurtosis & 0.359 \\
Skewness & 0.534 \\
Range & 7 \\
Minimum & 9 \\
Maximum & 16 \\
Sum & 298 \\
Count & 25 \\
\hline
\end{tabular}

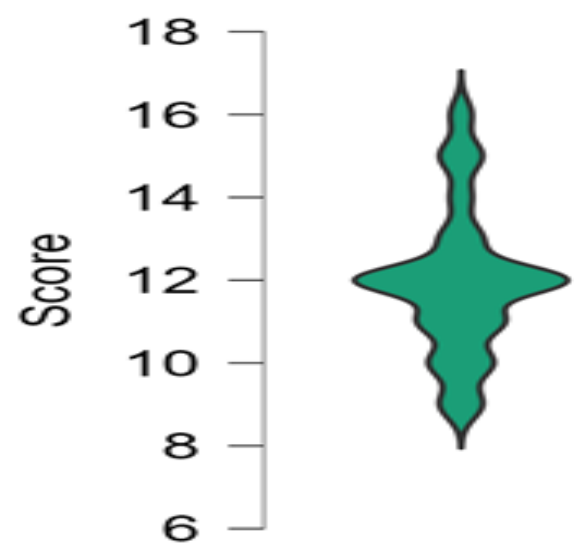

Figure 8. Diagram violin elements used for description distribution of scores related to the studied localities. Source: Own graphical representation using JASP.

To identify the localities and related scores, a color map is used in Figure 9. In order to distinguish the rank of localities according to the total score obtained, the color code presented in the legend of figure was used.

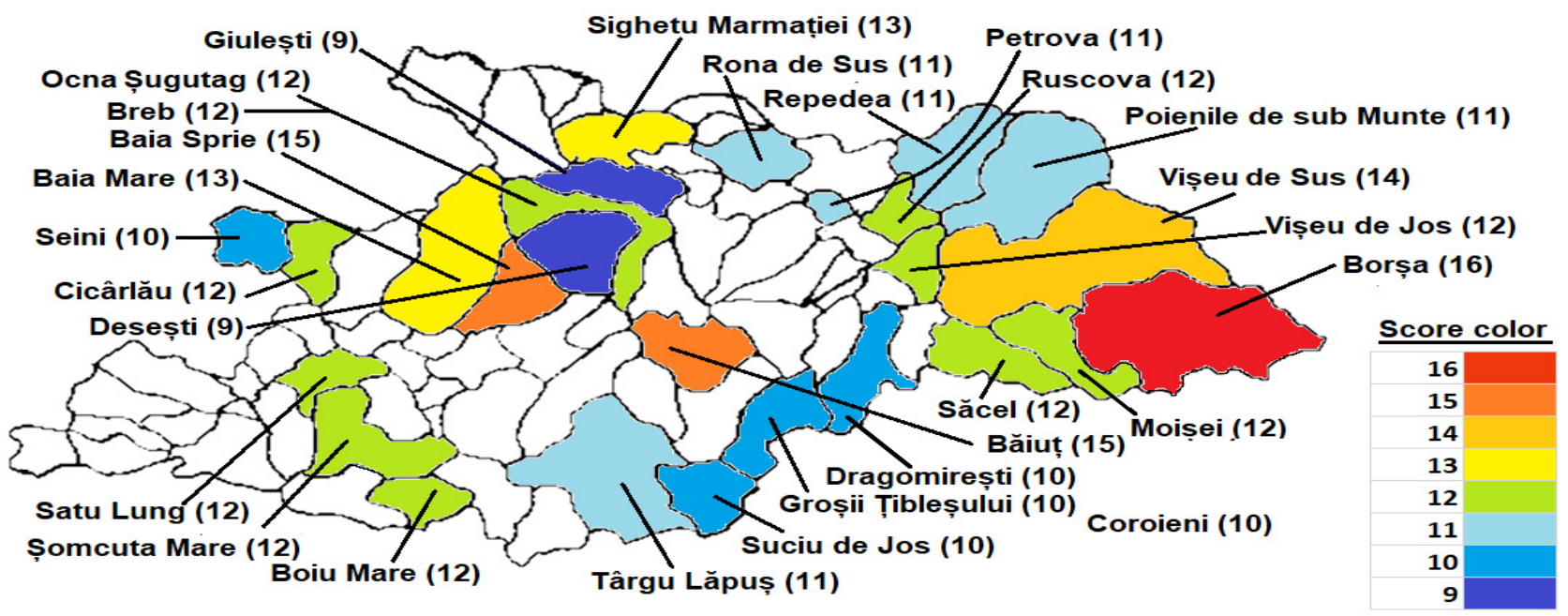

Figure 9. Map of Maramures County with the studied localities and the assigned score. Source: Own graphic representation.

As resulted from data processing on the localities studied, the main forms of tourism practiced in the studied area are contained in Table 9. 
Table 9. Characteristics of the types of tourism practiced in the research area.

Types of Tourism

$\mathrm{T} 1$

Ecotourism

$\mathrm{T} 2$

Mountain Tourism

T4

Rural

Tourism/Agritourism

T5

Cultural and

Scientific Tourism

More than $26 \%$ of the county's area is covered by protected natural areas, which are largely located in areas with great tourist flow. Ecotourism is the type of tourism that can be carried out in all the localities analysed because it meets all economic, social, aesthetic, tourism actors, maintaining cultural integrity, organic biological diversity, and all systems supporting life.

Has a great spread in the investigated localities, determined by the exceptional natural resources offered by the mountains surrounding the Depression of Maramures (on the upper course of River Tisa) to the west and south of Oaşului, Gutâi, Tibleş and Rodnei Mountains and to the east and north of Maramureş Mountains. Natural Park Maramureş Mountains is a protected area of national interest (IUCN-V) designated for the purpose of protecting biodiversity and it is located on the territorial administrative units of the localities Borşa, Vişeu de Sus, Poienile sub Munte, Repedea, Petrova, Bistra, Moisei, and Vişeu, where mountain tourism can be practiced. A variant of mountain tourism is winter sports tourism in Borşa, Cavnic, Căvior, Izvoare and Mogoşa near Baia Sprie or blue sports tourism - Lake Sports, Near Baia Sprie or Lake Zânelor in Mogoşa. On the Vaser, Mara, or Lăpuş rivers, one can practice rafting, kayaking or canoeing.

The reason for developing tourism in rural areas is small farmers' awareness of the need for diversification of the activity both on agricultural farms (agritourism) and outside, by engaging in forestry, tourism or appealing to certain activities specific to the local economy. Due to the richness of natural and anthropogenic resources, unique worldwide, in all 25 localities studied, rural tourism and agritourism can be practiced.

There are over 680 cultural heritage destinations of national and international interest, including: churches and assemblies, monuments and assemblies of architecture and arts, urban architectural assemblies, historical centers of which some are part of the UNESCO World Heritage. Ethnographic and folkloric Maramureş is also high originality, being represented by: the architecture specific to the villages in the Romanian historical provinces; Maramureş wooden churches; woodworking; folk outfit; the art of decoration; traditional ethnocultural and religious celebrations; fairs and ethnographic outdoor museum exhibitions or exhibition pavilions. Taking these elements, we also find that cultural, spiritual, and scientific tourism is specific to all localities in the protected areas of Maramureş.

T6

Religious (ecumenical) Tourism

$\mathrm{T} 7$

Mining Tourism

$\mathrm{T} 8$

Speleological Tourism

T9

Hunting and

fishing Tourism
Consists in the pilgrimages of believers to different cult buildings considered holy by different religions. To the same extent, the major cult premises, the saint patrons' days and the churches attract, during the traditional religious holidays, a considerable number of pilgrims. The tourism potential for this form of tourism in Maramures is particularly high and it is represented by the many monasteries, churches or other cult monuments that exist in all localities in the investigated areas.

Has emerged by touring the mining patrimony and by putting it into the tourist circuit. In Maramures, there are such mining areas attracted in the tourist circuit: Borşa, Cavnic, Sprie Baia or Speleo-mining circuit Cicariu-Poiana with Spines. The Mineralogical Museum of Baia Mare includes an impressive collection of minerals, fossils and rocks, of which around 1000 copies are unique in the world and that is one of the most visited tourist sites that include rare exhibits. A mining museum is also open in Baia Sprie, former mining town.

This type of tourism must be authorized by the Speleological Heritage Commission operating under the coordination of the Ministry of Environment. This committee is responsible for the authorization of speleological activities in caves; classifying in protective classes; assessment of caves based on scientific studies assumed; monitoring the preservation of the caves. Cave Baiu Mare, Cave Bătăţ, Cave Motori, Cave and the Blue Spring of Iza in Săcel, Cave Vălenii Mari- Şomcuta are declared monuments of nature and are designed to speleological tourism.

Hunting tourism addresses the lovers of hunting and fishing adventures. Maramureş is an area with many forests and fish rivers, and it has a rich and varied hunting fund. Maramures is the area with the best-preserved forest fund due to reduced deforestation. In Maramureş, 54 hunting funds are declared, with an area of over 600,000 ha (for Carpathian deer, black goat, deer, wild boar, fox) but the most important are: Babei Valley, Faena, Rica, Baicu Ieud, Black, Băiţa, Fersig, Strâmbu and T,ibles. Fishing can be practiced in the rivers: Mara, Tisa, Iza, Vişeu, Vaser, Cosău—a tributary of Mara, Lake Firiza, and in the bogs in the localities: Baia Mare-Firiza, Tăuții, Lăpușel, Câmpulung, Baia Sprie, Satulung.

T10

Dark-Tourism
Can be practiced with reference to visiting locations associated with suffering, death or other macabre events. Here is the Memorial of Communism and Resistance (Sighet Pain Memorial). 
The relevance of the study over time is given by the following aspects:

1. Includes approaches to the optimal use of environmental resources, the conservation of natural heritage and biodiversity (a key element in sustainable development);

2. It presents aspects related to the preservation of the socio-cultural authenticity of the host communities, the preservation of the cultural heritage and traditions over time (promotes intercultural understanding and tolerance, encourages the preservation of the built cultural heritage, traditional gastronomy, etc.)

3. It can stimulate the development of viable, long-term economic operations that provide socio-economic benefits to all parties involved (alleviating poverty by creating jobs, income and social services for host communities, safety issues for tourists, etc.).

4. Contributes to ensuring the satisfaction of tourists (promoting sustainable practices for the forms of tourism discussed), awareness of sustainability issues and media coverage of this region, in order to develop it sustainably.

\section{Conclusions}

Sustainable development represents the need for accountability and education for environmental protection, and this aspect is reflected in the evolution of Community Policy (marked by the transition from an approach based on coercion, sanction to a flexible, incentive-based approach). In our country it is acting (and) in the direction of a voluntary approach (based on legislation, the activity of NGOs), in order to promote the responsibility towards the environment among citizens, all economic and social partners, to encourage the use the environmental management methods.

Maramures is a geographical area in Romania with numerous natural and anthropogenic tourism resources: an important component of the natural framework of Maramureş are protected areas, which, through structure, size and diversity, can add value to the economy of localities in the area by capitalizing them touristically.

The grouping of rural communities located in the protected areas of Maramureş can be, for local administrations, a starting basis in developing future rural development strategies. They can be a starting point for discussions, a substantial aid in developing sustainable development strategies because many decisions directly influencing sustainability are taken at local community or micro-region levels.

The 25 localities identified provide opportunities for conducting different types of tourism and numerous tourist attractions included in the tourist circuit of the area, but insufficiently or improperly promoted. Identifying ten types of tourism in the studied localities can be the starting point in the establishment of the development strategies of those localities, in particular, and of the area, in general.

Despite the existence of a diversified tourist potential, Maramureş tourism still faces a low level of investment in the modernization of accommodation capacities and recreational bases, with a direct impact on the quality of the specific infrastructure, the duration of the stay, and the stability of the workforce specialized in the area.

Following research, studies, analyses, and interpretations, it was found that the following types of tourism have a high potential for development: ecotourism, cultural tourism, religious tourism, and hunting tourism that can be carried out in all studied localities. Given that more than $43 \%$ of the territory of the county is represented by the mountain area, as well as the fact that most tourist destinations are located in the mountains, more support measures for mountain tourism are needed.

Among sustainable tourist activities, mainly intended for young people, that can be practiced in compliance with the principles of sustainability and that fit the localities studied in the protected areas of Maramureş, could be the following: escalade, trekking, hiking, climbing, mountain climbing, biking, riding, rafting, canyoning, aerial sports, hunting, fishing, etc. 


\begin{abstract}
Author Contributions: All authors have contributed to the study and writing of this research. N.M.-S. and S.A. conceived the general idea of the research; C.R., C.M. and T.M. make the calculations of some indicators and realize the graphics; R.C., E.T., O.B. and S.A. carried out the direct investigation in the field and I.A.M. make the interpretations of the data and drew the main conclusions. All authors have read and agreed to the published version of the manuscript.
\end{abstract}

Funding: This research received no external funding.

Institutional Review Board Statement: Not applicable.

Informed Consent Statement: Was obtained an informed consent from the participants involved in this study.

Data Availability Statement: The data presented in this study/paper are available based on a request from the principal and corresponding author.

Acknowledgments: This research paper is supported by the project "Ensuring excellence in the activity of RDI within USAMVBT" code 6PFE, submitted in the competition Program 1-Development of the national system of research-development, Subprogram 1.2-Institutional performance, Institutional development projects-Development projects of excellence in RDI.

Conflicts of Interest: The authors declare no conflict of interest. The funding institute had no role in the design of the study; in the collection, analyses, or interpretation of data; in the writing of the manuscript, or in the decision to publish the results.

\title{
References
}

1. Word Tourism Organization. World Tourism Day 2021: Tourism for Inclusive Growth. Available online: https:/ /www.unwto. org/join-world-tourism-day-2021 (accessed on 26 November 2021).

2. Ciolac, R.; Iancu, T.; Brad, I.; Adamov, T.; Mateoc-Sîrb, N. Agritourism-A Business Reality of the Moment for Romanian Rural Area's Sustainability. Sustainability 2021, 13, 6313. [CrossRef]

3. Government of Romania. Tourism Development Strategy of Romania-Strategy and Action Plan (February 2019); Government of Romania: Bucharest, Romania, 2019; Volume 2. Available online: http://sgg.gov.ro/1/ (accessed on 25 November 2021).

4. Government of Romania; Ministry of Regional Development and Public Administration. Romania's Territorial Development Strategy (Polycentric Romania 2035-Territorial Cohesion and Competitiveness, Development and Equal Opportunities for People); Government of Romania: Bucharest, Romania, 2015.

5. Ciolac, R.; Iancu, T.; Brad, I.; Popescu, G.; Marin, D.; Adamov, T. Agritourism Activity-A "Smart Chance" for Mountain Rural Environment's Sustainability. Sustainability 2020, 12, 6237. [CrossRef]

6. Bâc, D.P. Turismul si Dezvoltarea Durabila—Realităti, Provocari, Oportunitati; Economica: Bucharest, Romania, 2013.

7. Talabă, I.; Gîtan, D.; Halle, A.P.; Ungureanu, D. Turismul Rural Românesc în Contextul Dezvoltării Durabile-Actualitate şi Perspective; Economic and Social Research Institute "Gheorghe Zane": Iași, Romania, 2010; Volume 20.

8. Milin, I.A.; Merce, I.I. Research on the tourist traffic in protected areas in Romania. Glob. J. Bus. Econ. Manag. 2020, 10, 83-90. [CrossRef]

9. Jain, P. Design thinking ... inspiring innovation, transforming humanity. Glob. J. Arts Educ. 2018, 8, 68-74. [CrossRef]

10. Patrascu, R.; Damian, A.; Minciuc, E. Problematici Fundamentale Privind Dezvoltarea Durabila; AGIR: Bucharest, Romania, 2015; ISBN 978-973-720-615-2.

11. Camarda, A.; Barsan, I.O. Dezvoltarea Durabila a Turismului Regional; Uranus: Bucharest, Romania, 2010 ; ISBN 9789737765833.

12. Mazilu, M. Turism si Dezvoltare Durabila; Universitaria Craiova: Craiova, Romania, 2011; ISBN 978-606-14-0238-0.

13. Bibirigea, R. Turismul Durabil—Oportunitati si Provocari; Universitara: Bucharest, Romania, 2009; ISBN 978-973-749-548-8.

14. WCED. Viitorul Nostru Comun; Oxford University Press: New York, NY, USA, 1987.

15. Nash, D.; Butler, R. Towards sustainable tourism. Tour. Manag. 1990, 11, 263-264. [CrossRef]

16. Butler, R.W. Tourism-An evolutionary perspective. In Tourism and Sustainable Development: Monitoring, Planning, Managing; Nelson, J.G., Butler, R.W., Wall, G., Eds.; University of Waterloo: Waterloo, UK, 1993; pp. 27-44.

17. May, V. Tourism, environment and development-Values, sustainability and stewardship. Tour. Manag. 1991, 12, 112-124. [CrossRef]

18. Sörensson, A.; von Friedrichs, Y. An importance-Performance analysis of sustainable tourism: A comparison between international and national tourists. J. Destin. Mark. Manag. 2013, 2, 14-21. [CrossRef]

19. Torres-Delgado, A.; López Palomeque, F. Measuring sustainable tourism at the municipal level. Ann. Tour. Res. 2014, 49, 122-137. [CrossRef]

20. Lee, T.H.; Hsin-Pei, H. Indicators of sustainable tourism: A case study from a Taiwan's wetland. Ecol. Indic. 2016, 67, 779-787. [CrossRef]

21. Khan, M.R.; Khan, H.U.R.; Lim, C.K.; Tan, K.L.; Ahmed, M.F. Ahmed, Sustainable Tourism Policy, Destination Management and Sustainable Tourism Development: A Moderated-Mediation Model. Sustainability 2021, 13, 12156. [CrossRef] 
22. Constantinescu, I.; Motatu, A.; Ionascu, G. Dezvoltare Durabilă si Civilizatie; Milena Press: Bucharest, Romania, 2019.

23. Ibănescu, B.C.; Stoleriu, O.M.; Munteanu, A.; Iațu, C. The Impact of Tourism on Sustainable Development of Rural Areas: Evidence from Romania. Sustainability 2018, 10, 3529. [CrossRef]

24. Sultan, M.T.; Sharmin, F.; Badulescu, A.; Stiubea, E.; Xue, K. Travelers' Responsible Environmental Behavior towards Sustainable Coastal Tourism: An Empirical Investigation on Social Media User-Generated Content. Sustainability 2021, 13, 56. [CrossRef]

25. Ban, O.; Hotos, A.; Droj, L.; Toderascu, C. Investigating the Image of the Bihor Tourist Destination among Romanians in the Context of Increasing Economic Indicators of Tourist Activity-25. Sustainability 2021, 13, 9002. [CrossRef]

26. Charter, M. Greener Marketing; Greenleaf: Sheffield, UK, 1992; ISBN 1874719004.

27. Mateoc-Sirb, N.; Toth, A.; Mateoc, T.; Manescu, C.; Dumitrescu, C. Aspects Regarding Rural Space Development And Life Improvement In Romania, Ecology, economics, education and legislation. SGEM 2016, 3, 43.

28. World Tourism Organization; Ecotourism and Protected Areas. Available online: https://www.unwto.org/sustainabledevelopment/ecotourism-and-protected-areas (accessed on 25 December 2021).

29. Government of Romania. DECISION no. 358 of May 30, 2019 Regarding the Approval of the National Ecotourism Development Strategy-Context, Vision and Objectives-2019-2029. Available online: https://legislatie.just.ro/Public/DetaliiDocument/2194 01 (accessed on 25 December 2021).

30. Hornoiu, R.I.; Padurean, M.A.; Nica, A.M.; Maha, L.G. Comportamentul de consum turistic în ariile naturale protejate. Amfiteatrul Econ. 2014, XVI, 961-974.

31. Bădulescu, A.; Bâc, D. Profile of ecotourists in the Apuseni Mountains natural park. GeoJournal Tour. Geosites 2009, 3, 7-16.

32. Dologlou, N.; Katsoni, V. Ecotourism in protected areas, a literature review. ECOCLUB Com. Ecotourism Pap. 2016, 38, 1-20.

33. IUCN-A Brief History. Available online: https:/ / www.iucn.org/about/iucn-a-brief-history (accessed on 25 November 2021).

34. IUCN/SSC. Strategic Planning for Species Conservation: A Handbook. Version 1.0; IUCN Species Survival Commission: Gland, Switzerland, 2008; ISBN 978-2-8317-1125-6.

35. Bleahu, M. Ariile Protejate si Protectia Naturii; Paideia: Bucharest, Romania, 2019; ISBN 9786067482362.

36. Smaranda, J.S. Managementul Turismului în Ariile Protejate; Risoprint: Cluj-Napoca, Romania, 2008; ISBN 978-973-751-714-2.

37. Baltaretu, A.M. Arii Protejate; Prouniversitari: Bucharest, Romania, 2011.

38. Burns, K. The National Parks—American Best Idea; KNOPF: New York, NY, USA, 2009.

39. Katsoni, V.; Dologlou, N. ICT Applications in Smart Ecotourism Environments. In Smart Cities in the Mediterranean; Stratigea, A., Kyriakides, E., Nicolaides, C., Eds.; Springer: Cham, Switzerland, 2017. [CrossRef]

40. Official Journal of the European Union. Council Directive 92/43/EEC of 21 May 1992 on the Conservation of Natural Habitats and of Wild Fauna and Flora. Available online: https://eur-lex.europa.eu/legal-content/RO/TXT/?uri=celex\%3A31992L0043 (accessed on 16 December 2021).

41. Official Journal of the European Union. Commission, Implementing Decision of 11 July 2011 Concerning a Site Information Format for Natura 2000 Sites. Available online: https:/ / eur-lex.europa.eu/legal-content/EN/TXT/?uri=CELEX\%3A32011D0484 (accessed on 16 December 2021).

42. European Commission; Directorate-General for Environment; Sundseth, K. Natura 2000: Protecting Europe's Biodiversity; Wegefelt, S., Mézard, N., Eds.; European Commission: Brussels, Belgium, 2008. Available online: https://data.europa.eu/doi/10.2779/45 963. (accessed on 25 December 2021).

43. Government of Romania. Emergency Ordinance No. 57 of June 20, 2007 on the Regime of Protected Natural Areas, Conservation of Natural Habitats, Wild Flora and Fauna (Official Gazette No. 442 of June 29, 2007); Government of Romania: Bucharest, Romania, 2007.

44. Government of Romania; Ministry of Environment. Order of the Minister of Environment and Forests No. $3836 / 2012$ on the Approval of the Methodology for Approving the Tariffs Established by the Administrators/Custodians of Protected Natural Areas for Visiting Protected Natural Areas, for Analyzing Documentation and Issuing Approvals According to Law, for Photography and Filming for Commercial Purposes (Official Gazette No. 854 of December 18, 2012); Government of Romania: Bucharest, Romania, 2012.

45. Government of Romania. Government Decision 1284 / 2007 on the Declaration of Special Avifauna Protection Areas as an Integral Part of the Natura 2000 Network in Romania (Official Gazette No. 739/31.10.2007); Government of Romania: Bucharest, Romania, 2007.

46. Government of Romania; Ministry of Environment. Order of the Minister 1710/2007 Regarding the Approval of the Necessary Documentation in Order to Establish the Regime of Protected Natural Area of National Interest (Official Gazette 815/29 November 2007); Government of Romania: Bucharest, Romania, 2007.

47. Government of Romania; Ministry of Environment. Order of the Minister 1964/2007 on the Establishment of the Protected Natural Area Regime of Sites of Community Importance, as an Integral Part of the European Ecological Network Natura 2000 in Romania (Official Gazette no. 98/07.02.2008); Government of Romania: Bucharest, Romania, 2008.

48. Government of Romania. National Agency for Protected Natural Areas. Available online: http://ananp.gov.ro/wp-content/ uploads/inventar_arii_Ro_v1-00000003.pdf (accessed on 16 December 2021).

49. Otiman, P.I.; Florian, V.; Ionescu, C. Conservarea Geo-și Biodiversității și Dezvotarea Durabilă în Tara Hațegului-Retezat; Romanian Academy: Bucharest, Romania, 2010; Volume 2, pp. 67-68.

50. How to Use JASP. Available online: https:/ /jasp-stats.org/how-to-use-jasp/ (accessed on 15 December 2021).

51. Geographical Map of Romania. Available online: https://harta-romaniei.org/harta-geografica-a-romaniei.html (accessed on 19 November 2021).

52. Maramureş County. Directorate of Statistics. Available online: https://maramures.insse.ro/ (accessed on 17 November 2021). 
53. Romanian Parliament. Low No.290/2018 for the Amendment and Completion of Law No. 2/1968 Regarding the Administrative Organization of the Romanian Territory (Official Gazette no. 1052/12.12.2018); Romanian Parliament: Bucharest, Romania, 2018.

54. Maramures County Council. Available online: https:/ /www.cjmaramures.ro/ (accessed on 25 December 2021).

55. National Institute of Statistics. Available online: http/ / statistici.insse.ro/tempo-online (accessed on 19 November 2021).

56. Porumb, M. Biserici de Lemn din Maramures; Romanian Academy: Bucharest, Romania, 2005; ISBN 973-27-1257-0.

57. Man, G. Biserici de Lemn din Maramures, Proema: Baia Mare, Romania, 2005; ISBN 973-8013-45-3.

58. Otiman, P.I.; COLAB, M.S.N.Ş. Dezvoltarea Rurală Durabilă în România; Romanian Academy: Bucharest, Romania, 2006.

59. Mateoc-Sirb, N.; Otiman, P.I.; Mateoc, T.; Manescu, C. The Evolution of Romanian Villages Since the Great Union of 1918. Transylv. Rev. 2018, 27, 249-261, WOS:000460088300020.

60. Man, G.; Gaftone, V. Coordinators-Maramureş: The Treasure from the Geografical Center of Europe, 2nd ed.; Maramureş County Council, Maramureş County Museum, Eds.; Proema: Baia Mare, Romania, 2003.

61. Ivaniuc, T. Ghidul Turistic al Tării Maramureșului; Limes: Cluj-Napoca, Romania, 2006.

62. Romanian National Bibliography, Publishing House of the National Library of Romania. Available online: https: / / aleph.bibnat. ro/F?RN=886363533 (accessed on 31 October 2021).

63. Toth, A.; Mateoc-Sirb, N.; David, S.; Mateoc, T.; Manescu, C.; Venig, A.; Sarb, G. Organic agriculture: An opportunity for sustainable development of Romanian villages. J. Biotechnol. 2016, 231, S83. [CrossRef]

64. Gavrilescu, C.; Florea, A.; David, S.; Popescu, A.; Mateoc-Sirb, N. Agri-food organic products-A fast increasing market. J. Biotechnol. 2016, 231, S94. [CrossRef]

65. Tigan, E.; Brînzan, O.; Obrad, C.; Lungu, M.; Mateoc-Sîrb, N.; Milin, I.A.; Gavrilaș, S. The Consumption of Organic, Traditional, and/or European Eco-Label Products: Elements of Local Production and Sustainability. Sustainability 2021, 13, 9944. [CrossRef] 